\title{
Inteligencja, socjalizm i rewolucja w myśli politycznej Jana Wacława Machajskiego (1866-1926)
}

\begin{abstract}
Abstrakt: Artykuł przedstawia poglądy Jana Wacława Machajskiego dotyczące socjalizmu, rewolucji oraz politycznej roli i pozycji inteligencji. Autor podkreśla, że w ujęciu polskiego myśliciela inteligencja była specyficzną warstwą społeczną. Przede wszystkim grupą interesu, wybitnie egoistyczną, pozbawioną jakiegokolwiek etosu czy altruizmu, poczucia odpowiedzialności i służebności wobec słabszych grup społecznych. Warstwą aspirującą do wysokiego statusu materialnego oraz władzy. Manipulującą teorią i praktyką socjalizmu, zgodnie z przekonaniem, że wszelkie koncepcje, teorie i działania socjalistyczne, z marksizmem na czele, są jedynie metodą zabezpieczenia inteligenckich interesów.
\end{abstract}

Słowa kluczowe: socjalizm, rewolucja, inteligencja („pracownicy umysłowi”), społeczeństwo burżuazyjne, proletariat, Jan Wacław Machajski, Stefan Żeromski, Johann Karl Rodbertus-Jagetzow, Karl Marx, Władimir I. Lenin, Eduard Bernstein, Karl Kautsky.

Abstract: The article presents Jan Wacław Machajski's views on socialism and revolution as well as the political role and position of intellectuals. The author emphasizes that in the Polish thinker's view, the intelligentsia was a specific social strata. First of all, it was an interest group, extremely selfish, devoid of any ethos or altruism, a sense of responsibility and servitude towards weaker social groups. A strata aspiring to high material status and power. The manipulative theory and practice of socialism, in line with the conviction that all concepts, theories and socialist activities, with Marxism at the forefront, were only a method of securing interests of their group.

Keyw ords: socialism, revolution, intelligentsia ("white-collar workers"), bourgeois society, proletariat, Jan Wacław Machajski, Stefan Żeromski, Johann Karl Rodbertus-Jagetzow, Karl Marx, Vladimir I. Lenin, Eduard Bernstein, Karl Kautsky. 
Rewolucji przemysłowej w Wielkiej Brytanii, a następnie w innych krajach zachodnioeuropejskich towarzyszyły szybkie, dogłębne przemiany ustrojowe. Było to wynikiem oddziaływania nowych technologii, które sprzyjały, pobudzały ewolucję, a w zasadzie, biorąc pod uwagę tempo wydarzeń, rewolucję w strukturach gospodarczych, społecznych i politycznych. I to na skalę niespotykana w poprzednich epokach. Dotychczasowe układy i struktury społeczne, składające się z mniejszych czy większych właścicieli ziemskich, tj. szlachty, arystokracji i przedstawicieli kleru, a także różnych grup i kategorii chłopów i nie mniej zróżnicowanej ludności miejskiej, ulegały znaczacym przemianom i przekształceniom, i co istotne - stopniowo traciły swoja wielowiekowa, dominująca pozycję; w sensie przewagi zarówno politycznej, jak i ilościowej. Bardzo często było to równoznaczne także z utratą wysokiej pozycji społecznej, z ustapieniem miejsca warstwom czy klasom, które dotychczas w ogóle nie istniały lub występowały jedynie w zalążkowej postaci. Mam na myśli burżuazję, inteligencję oraz wielkoprzemysłową klasę robotniczą ${ }^{1}$. Niezależnie od oczywistego skądinąd faktu, że wielkości i znaczeniu politycznemu proletariatu nie towarzyszyły ani prestiż społeczny, ani wysoki status materialny.

Nowe, rosnące grupy społeczne naturalną koleja rzeczy miały własne cele i interesy, zarówno materialne, jak i polityczne. Musiały je precyzować, wyrażać, uzasadniać. To zaś sprzyjało, a nawet wymuszało powstawanie różnych koncepcji, różnych rozwiązań społecznych, ustrojowych, politycznych. Sprzyjały temu również tarcia, napięcia, sprzeczności i walki - zarówno między tymi grupami, jak i z przedstawicielami zanikającego systemu feudalnego ${ }^{2}$. Niewątpliwie trafne jest stwierdzenie, że XIX stulecie przynosiło „wzmożone zainteresowanie problematykami struktury społecznej”3. W rezultacie mieliśmy wówczas do czynienia z powstawaniem różnorodnych teorii, utopii, idei oraz ideologii. Piszac nieco umownie, metaforycznie, parafrazując znane określenie - „z początkiem wieku ideologii”"

${ }^{1}$ Wielkoprzemysłowa, a więc zatrudnianą w wielkich, jak na ówczesne czasy, przedsiębiorstwach przemysłowych posługujących się - w odróżnieniu od manufaktur - maszynami i pracujaca $\mathrm{w}$ coraz bardziej zautomatyzowanym procesie produkcji.

${ }^{2}$ Szerzej zob. M.J. Zacharias, Putevi i bespuća revolucionarne misli. Slučaj Jana Vaclava Mahajskog i Milovana Đilasa, w: Jugoslavija i Poljska u XX veku. Međunarodni tematski zbornik radova sa konferencije Jugoslovensko-poljski odnosi u XX veku, red. M. Pavlović, A. Zaćmiński, P. Wawryszuk, Beograd 2017, s. 349 i n.; wersja anglojęzyczna: Intelligentsia and New Class. Political elites according to Jan Wactaw Machajski and Milovan Djilas, „Studia z Dziejów Rosji i Europy Środkowo-Wschodniej” 2017, t. LII, Special Issue, z. 3, s. $157 \mathrm{i} \mathrm{n.}$

${ }^{3}$ L. Dubel, Totalna negacja inteligencji. Idee Jana Wacława Machajskiego i Michała Bakunina, „Studia nad Autorytaryzmem i Totalitaryzmem” 2016, t. XXXVIII, nr 4, s. 69.

${ }^{4}$ Mam na myśli parafrazę głośnej pracy Daniela Bella, pt. The End of Ideology. On the Exhaustion of Political Ideas in the Fifties (Glencoe 1960). Pewne elementy tego sposobu myślenia znajdowały się również w twórczości wybitnego francuskiego myśliciela Raymonda 
Nowe ideologie przedstawiali wyraziciele różnych elit, kierunków, pradów umysłowych czy politycznych: demokraci, socjaliści, socjaldemokraci, anarchiści, liberałowie, nacjonaliści, konserwatyści, monarchiści, republikanie. Odpowiadały one nowym potrzebom, nowym sytuacjom, wyrażały nowatorskie koncepcje, tendencje intelektualne. Służyły interpretacji nowo powstającej rzeczywistości, wschodzącego, nieznanego świata, jakże odmiennego od dotychczasowego. Zanikającego, ale jeszcze istniejącego, może nie zawsze najwygodniejszego, często podważanego czy kwestionowanego, ale znanego od stuleci, na swój sposób - „oswojonego”. Niekiedy zawierały one rozwiązania, o których dzisiaj można by powiedzieć, że były ryzykowne, utopijne, niewykonalne czy też szkodliwe. Ale również i to, że zawarte w nich odpowiedzi na pytanie, jak postępować, jak reagować na gwałtowne, nieznane dotąd przemiany, w istocie często tylko takie właśnie musiały być - wątpliwe i pozbawione kontaktu z rzeczywistościa.

W rezultacie wśród teoretyków, ideologów, pisarzy politycznych z przełomu XIX i XX w. często pojawiały się osobistości szczególne, specyficzne, zadziwiające oryginalnościa swoich poglądów. Niewattpliwie należał do nich również polski myśliciel Jan Wacław Machajski. W jego teoriach, w poglądach, które głosił, wyraźnie były widoczne zasadnicze dylematy epoki, a także sądy i opinie, które dzisiaj moga się wydawać nie tylko błędne, ale i zadziwiająco naiwne. Co nie zmienia faktu, że niekiedy były nowatorskie, zaskakująco trafne, nawet po śmierci Machajskiego, w odniesieniu do rzeczywistości drugiej połowy XX stulecia. Co więcej, właściwie można by stwierdzić, że w dużej mierze to właśnie specyfika tych poglądów, ich niepowtarzalność, usytuowanie na pograniczu ekstrawagancji intelektualnej pociagały za sobą brzemienne, niekorzystne konsekwencje: całkowite odrzucenie myśli Machajskiego przez teoretyków oraz ideologów socjalistycznych na przełomie XIX i XX w., a więc $\mathrm{w}$ momencie, w którym ta myśl się pojawiła. To odrzucenie było zreszta widoczne także w kolejnych dekadach XX stulecia: za życia i po śmierci autora Pracownika umystowego. Niewątpliwie w związku z faktem, że polski myśliciel paradoksalnie mieścił się i wyłamywał z socjalistycznych schematów myślowych i preferowanych form działania. Z jednej strony bowiem głosił potrzebę przeprowadzenia - jak można by powiedzieć - „rewolucji proletariackiej”, z drugiej zaś - co przynajmniej pozornie mogłoby wydawać się dosyć perwersyjne - zdecydowanie potępiał wszelkie formy i odmiany socjalizmu. W swojej twórczości wyraźnie ustawiał się w roli przeciwnika socjalistów, zarówno tych, którzy mówili o potrzebie, jak uważał, własnej, socjalistycznej rewolucji, jak i tych, którzy wzorem Eduarda Bernsteina preferowali ewolucyjne dążenia - reformistyczne i rewizjonistyczne. W rezultacie trudno

Arona (L'opium des intellectuels, Paris 1955). Zob. także ciekawe rozważania polskiego znawcy przedmiotu Marcina Króla, Koniec wieku ideologii,www.newsweek.pl/europa/ koniec-wieku-ideologii,44602,l.html (dostęp: 18 XI 2016). 
byłoby jednoznacznie zakwalifikować Machajskiego do określonej, szerszej tradycji, formacji - politycznej oraz intelektualnej. Niekiedy spotykamy się z poglądem, aczkolwiek wyrażanym z pewnymi zastrzeżeniami, że można by go umieścić „, szerokim nurcie myśli anarchistycznej”. Jak zobaczymy, polski myśliciel będzie zdecydowanie odcinał się od ruchu anarchistycznego.

Można przypuszczać, że wspomniane, prawie powszechne odrzucenie stało się również jednym z powodów stosunkowo słabej znajomości, stosunkowo niewielkiego zainteresowania historyków poglądami Machajskiego. Wiedzę w tym zakresie posiada jedynie ograniczone grono badaczy - polskich i zagranicznych ${ }^{6}$. Uprawnione wydaje się przypuszczenie, że brak większej ilości szczegółowych badań w przeszłości wynikał także z niedostępności tekstów Machajskiego ${ }^{7}$, potępienia jego poglądów w Związku Sowieckim w latach dwudziestych i trzydziestych XX stulecia ${ }^{8}$, niezgodności jego teorii z oficjalna, bardzo często uproszczona, w istocie prostacką wykładnią marksizmu w ZSRS,

${ }^{5}$ Zdaniem Antoniego A. Kamińskiego można by to uczynić „głównie ze względu na odrzucenie celów politycznych jako jednego z najważniejszych postulatów ruchu robotniczego". Ten sam autor trafnie dodaje, że Machajski „za anarchistę się nie uważał i z żadnym z odłamów anarchizmu się nie identyfikował”. A.A. Kamiński, Socjalizm jako wymyst inteligencji. O życiu i pogladach Jana Wactawa Machajskiego, „Prace Naukowe Akademii Ekonomicznej we Wrocławiu. Nauki Humanistyczne" 2003, t. VIII, s. 50-51. Natomiast Leszek Gawor dosyć ryzykownie dostrzega w twórczości Machajskiego „wyraźne motywy anarchistyczne” oraz wpływy anarchizmu kolektywnego Michaiła Bakunina. Zob. L. Gawor, Machajskiego teoria socjalistycznej rewolucji, „Wschodni Rocznik Humanistyczny” 2007, t. IV, s. 156, 160; idem, Filozofia społeczna Jana Wactawa Machajskiego, „Archiwum Historii Filozofii i Myśli Społecznej” 2009, t. LIV, s. 100.

${ }^{6}$ Najważniejsze opracowania poświęcone Machajskiemu i jego poglądom: M. Nomad, The Saga of Wactaw Machajski, w: idem, Aspects of Revolt, New York 1959; idem, Dreamers, Dynamiters, and Demagogues, New York 1964; A. d'Agostino, Intelligentsia Socialism and the „Worker's Revolution”. The Views of J.W. Machajski, „International Review of Social History" 1969, nr 4, s. 54-89; M.S. Shatz, Jan Wactaw Machajski. A Radical Critic of the Russian Intelligentsia and Socialism, Pittsburgh (Pa.) 1989; L. Dubel, Zapomniany prorok rewolucji. Szkic o Janie Wactawie Machajskim, Lublin 2009; idem, Życiowe przypadki $i$ wybory Jana Wacława Machajskiego, w: J.W. Machajski, Robotnik umystowy 1911, oprac. L. Dubel, Zamość 2012; P. Laskowski, Jan Wacław Machajski: jasnowidz i prorok, w: J.W. Machajski, Pracownik umystowy $i$ inne pisma, wprowadzenie, red. nauk. P. Laskowski, Warszawa 2016, s. 7-88.

${ }^{7}$ Najważniejsze teksty Machajskiego były pisane po rosyjsku, powielane na hektografie, ukazywały się w niewielkiej liczbie egzemplarzy. Zob. też: przypis 25.

${ }^{8}$ Por. N. Baturin, Pamiati machajszcziny, „Prawda”, 2 III 1926. 12 lat później, tj. 14 XI 1938 r. sowieccy przywódcy postanowili „wykarczować resztki machajszczyzny”, nakazując wszystkim organom WKP/b „położyć kres machajszczykowskiemu antyleninowskiemu stosunkowi do inteligencji”. W tym duchu była utrzymana treść artykułu w „Prawdzie” z 18 listopada tego roku, pt. Otwiety na woprosy czitateliej. Czto takoje machajszczina? Myśl Machajskiego została tam określona jako koncepcja „dzika, chuligańska i szkodliwa dla państwa sowieckiego". Istotą poglądów Machajskiego rzekomo miało być szerzenie wspomnianego „chuligaństwa” i wrogiego stosunku do sowieckiej inteligencji. Z. Zaremba, Stowo o Wacławie Machajskim, Paryż 1967, s. 116-122. Zob. też: P. Laskowski, op. cit., s. 62. 
PRL i pozostałych krajach tzw. demokracji ludowej ${ }^{9}$. Nie bez znaczenia mogły być również bardziej prozaiczne względy, np. wyraźne wady i słabości pisarstwa Machajskiego. Zygmunt Zaremba trafnie zauważa, że jest ono „ciężkie, często zagmatwane, pełne powtórzeń i dygresji” ${ }^{10}$. Zdaniem innego badacza Machajski „wciąż miesza wątki, brak mu widocznej i przemyślanej struktury argumentacji, a od precyzji wyrażenia ważniejszy jest retoryczny efekt”. Wszystko to sprawia, że nawet osoby obyte „z językiem epoki i ówczesna literatura socjalistyczną czy anarchistyczną" mogą mieć pewne trudności z percepcją myśli i argumentacji autora Pracownika umystowego ${ }^{11}$. Niewątpliwie brak mu było odpowiednich zalet, głównie precyzji i talentu literackiego.

Jan Wacław Machajski urodził się 27 XII 1866 r. w Busku, ówcześnie w guberni kieleckiej. Uczył się w progimnazjum w Pińczowie, a następnie w gimnazjum w Kielcach. Był kolega, a nawet przyjacielem szkolnym Stefana Żeromskiego, który później nadał rysy Machajskiego kilku bohaterom swoich dzieł literackich ${ }^{12}$. Żeromski pisał, że jego przyjaciel „był to w szkołach złoty uczeń, prymus, medalista, niezwykła i wszechstronna zdolność, umysł lotny i badawczy, a nadto dusza czysta, ofiarna, prawa, charakter niezłomny i żelazna wola". Empatię i wybitne zdolności podkreślał również inny kolega szkolny Machajskiego, Jan Stróżecki, późniejszy działacz socjalistyczny ${ }^{13}$.

Po ukończeniu gimnazjum Machajski rozpoczął w 1886 r. studia przyrodnicze, a następnie medyczne na Uniwersytecie Warszawskim. Później studiował w Genewie, ale nigdy nie uzyskał dyplomu. Wynikało to nie tylko z trudności finansowych, z którymi w praktyce borykał się niemalże przez całe życie, ale również z faktu, że gros swojego czasu poświęcał działalności pozastudenckiej, początkowo oświatowej, patriotycznej, narodowej. Był członkiem Związku Młodzieży Polskiej, tzw. Zetu. Z czasem coraz bardziej interesował się problematyka społeczna, głównie kwestia robotnicza. W końcu lat osiemdziesiątych XIX w. podzielał poglądy narodowe i socjalistyczne zarazem, wyrażane przez Bolesława Limanowskiego i na łamach pisma „Pobudka” wydawanego w Paryżu ${ }^{14}$, następnie zaś - tylko socjalistyczne. Tę stopniową ewolucję ideową, stopniowe

${ }^{9}$ L. Dubel, Życiowe przypadki..., s. 46.

${ }_{10}$ Z. Zaremba, op. cit., s. 122.

11 Ibidem, s. 380-381.

${ }^{12}$ Mam na myśli Andrzeja Radka w Syzyfowych pracach, Zagozdę w Róży i Żłowskiego w Nawracaniu Judasza. P. Laskowski, op. cit., s. 10. Czasami jako datę urodzin Machajskiego podaje się 8 I 1867. Zob. ibidem, s. 9, przypis 11.

${ }^{13}$ S. Żeromski, W sprawie Machajskiego (1911), w: idem, Elegie i inne pisma literackie $i$ społeczne, Warszawa-Kraków 1928, s. 103-118, przedruk eseju zamieszczonego w piśmie „Nowa Reforma”, 7 II 1911, dostępnego również w internecie: http://lewicowo.pl/w-sprawie-machajskiego/; Wspomnienia Jana Stróżeckiego, oprac. J. Kancewicz, R. Stanisławska, F. Tych, „Archiwum Ruchu Robotniczego” 1977, t. IV, s. 40.

${ }^{14}$ A.A. Kamiński, op. cit., s. 55; D. Zych, Jan Wacław Machajski (Zagadnienia biografii), w: Historia i kultura. Studia z dziejów polskiej myśli kulturalnej, t. II, red. A. Mencwel, Warszawa 1991, s. 170. 
porzucanie ideałów patriotycznych i narodowych zauważał Żeromski. Już we wrześniu 1887 r. notował, że Machajski „sczerwieniał tak bardzo, iż zaczyna się zabarwiać na karminowo. Jeszcze chwila a rozpryśnie się w przestrzeń" ${ }^{15}$.

Odchodzenie od zaangażowania w sprawy narodowe zbiegło się w czasie z przekonaniem Machajskiego o negatywnej roli społecznej i politycznej inteligentów. To właśnie wtedy zaczyna on coraz mocniej wyrażać przekonanie, że jest ona szkodliwa z punktu widzenia socjalizmu oraz interesów proletariatu. Machajski z wyraźną niechęcią odnosi się do nadmiernego, jak uważa, udziału młodzieży inteligenckiej w ruchu socjalistycznym. Twierdzi, że stanowi ona „podatny materiał do wszelkiej rewolucyjnej działalności”, ale równocześnie poddaje się wpływom tendencji, które nie mają nic wspólnego z socjalizmem. Obawia się „rozmiękczenia” socjalizmu przez żywioły „burżuazyjno-inteligenckie”16. Uważa, że „patrioci stawali się socjalistami”, ale tylko po to, aby wciagnać masy ludowe do walki za „ojczyzne””. Jego zdaniem młodzi inteligenci myślą nie „o oswobodzeniu mas ludowych”, lecz o „niepodległym państwie polskim”. Miałoby to świadczyć o tym, że „inteligencja wyzyskuje socjalizm dla swoich własnych interesów". W rezultacie pojawia się zdecydowanie wrogi stosunek Machajskiego „do wszelkiego rodzaju «narodowych ruchów wolnościowych», do wszelkiej walki za ojczyznę. "Zawsze i wszędzie à bas la patrie»"17. Nie dziwi więc opinia Żeromskiego ze stycznia 1892 r., wyrażona po spotkaniu z Machajskim w Genewie, że jego przyjaciel stał się jednym „z wielu postępowców, wyśmiewających dziś to, za co wczoraj gardło dawał [...] z wyżyn doktrynek - pisał - jakie obecnie trzyma w pachcie zarzuca mi wstecznictwo, konserwatyzm, filisteryja [...] jest to szlachetny chłopiec, dobry doktryner, ale nie podobny do dawnego Wacka"18. W tym miejscu należy zaznaczyć, że kiełkująca, krytyczna ocena inteligenckich postaw, ujawniona właśnie wtedy, już wkrótce stanie się przewodnia, najważniejszą częścią teorii Machajskiego.

Od początku ostatniej dekady XIX stulecia Machajski coraz wyraźniej angażuje się w działalność socjalistyczna, konkretnie II Proletariatu. 15 VI 1892 r. zostaje zatrzymany i osadzony w Cytadeli warszawskiej za próbę przemycenia do Królestwa Polskiego odezwy do robotników, nawołującej do rozszerzenia na cały kraj fali strajków, jakie właśnie w tym roku miały miejsce w Łodzi. Po długotrwałym śledztwie otrzymuje wyrok trzech lat więzienia i pięciu lat zsyłki na Syberii. Jest więziony w Warszawie i Petersburgu, a następnie zostaje zesłany do Wilujska na Syberii ${ }^{19}$.

${ }_{15}$ S. Żeromski, Dzienniki, t. II, oprac. J. Kądziela, Warszawa 1964, s. 417.

16 J.W. Machajski, $Z$ życia konspiracyjnego $w$ Kongresówce, „Pobudka” 1892, s. 3-4, cyt. za: D. Zych, op. cit., s. 171.

17 W. Machajska, Życie i poglady Wacława Machajskiego, „Wiadomości”, (Londyn) 4 III 1962, nr 9 (831), www.przeglad-anarchistyczny.org/opracowania-historyczne/201-zycie-i-poglady-waclawa-machajskiego (dostęp: 24 II 2016).

18 S. Żeromski, Elegie..., s. 386; P. Laskowski, op. cit., s. 11-12.

${ }^{19}$ L. Dubel, Życiowe przypadki..., s. 17-18; P. Laskowski, op. cit., s. 12. 
W czasie zsyłki Machajski precyzuje swoje poglądy. Dosyć paradoksalnie sprzyjały temu warunki katorgi: „więzienia carskie były szkołą i uniwersytetem rewolucjonistów. Rzadko stosowano w nich tortury fizyczne, jeśli nie liczyć skucia kajdanami więźni skazanych na katorgę [...]. W więzieniu carskim można było czytać, dopełniać wykształcenia, a przede wszystkim myśleć i wgłębiać się w siebie”. Nie wymyślono jeszcze „metod łamania indywidualności i prania mózgów. Wszystko to dopiero przyjdzie, gdy spełni się jedno z ponurych proroctw Machajskiego" ${ }^{20}$, a więc po zwycięstwie „socjalistycznej” rewolucji w Rosji. Na przełomie zaś XIX i XX stulecia zesłańcy i więźniowie na dalekiej Syberii mieli do dyspozycji liczne książki i wydawnictwa prasowe - „dzieła Marksa, Engelsa, Kautsky'ego [...] czasopisma rosyjskie [...] komplety «(Die) Neue Zeit» za szereg lat”21. Jednemu ze „współtowarzyszy zesłania” Machajskiego „udało się przewieść całą bibliotekę [...] wydawnictw socjalistycznych" (sic!) ${ }^{22}$. W tych warunkach uprawnione wydaje się stwierdzenie, że pewne cechy systemu penitencjarnego carskiej Rosji były wówczas pozbawione sensu i logiki. Karano bowiem za działalność rewolucyjna, ale równocześnie tolerowano sytuację, która pozwalała wywrotowcom, rewolucjonistom nabywać odpowiednią wiedzę potrzebną czy wręcz niezbędną dla urzeczywistnienia ich celów i zamysłów ${ }^{23}$.

W rezultacie zaopatrzony w książki i czasopisma Machajski będzie miał „możność - jak pisze - zastanowić się gruntownie nad pewnymi kwestiami i zdobyć [...] własny punkt widzenia na rozmaite sprawy"24. Swój czas na zesłaniu dzielił na lektury, przemyślenia, dyskusje i przelewanie myśli na papier. Napisał wówczas dwie prace: Ewolucja socjaldemokracji oraz Naukowy socjalizm ukończone odpowiednio w 1899 i 1900 r. Powielone na hektografie krążyły one po różnych miejscowościach na Syberii. Wzbudziły spore, choć powierzchowne zainteresowanie, m.in. Lwa Trockiego ${ }^{25}$. Nieco później

${ }^{20}$ Z. Zaremba, op. cit., s. 39.

${ }^{21}$ W. Machajska, op. cit.

${ }^{22}$ D. Zych, op. cit., s. 174.

${ }^{23}$ Być może było to pochodną dosyć zasadniczej sprzeczności występującej w polityce caratu, dostrzeżonej przez Richarda Pipesa. Sprzeczności polegającej na umożliwianiu „poddanym niemal nieograniczonego dostępu do wiedzy" przy jednoczesnym pozbawianiu ich praw politycznych. R. Pipes, Piotr Struwe. Liberat na lewicy 1870-1905, tłum. S. Szymański, Warszawa 2016, s. 253. Co ciekawe, podobne zjawisko występowało w niektórych dyktaturach międzywojennych. Milovan Đilas wspomina, że w czasie uwięzienia w latach 1933-1936 miał możliwości, podobnie jak inni więzieni komuniści, studiować dzieła twórców marksizmu. Zob. M.J. Zacharias, Idee, utopie, rzeczywistość. Myśl polityczna Milovana Đilasa (1911-1995), Bydgoszcz 2015, s. 35-36.

${ }^{24}$ J.W. Machajski w liście do S. Żeromskiego z 24 II 1904 r., w: S. Pigoń, Miłe życia drobiazgi. Pokłosie, Warszawa 1964, s. 364.

25 Szczegóły zob. L. Trocki, Wospominanja o mojej pierwoj sibirskoj ssytkie, „Katorga i ssyłka” 1923, nr 5, s. 91-95; idem, Moje życie, Warszawa 1930, s. 144-145; P. Laskowski, op. cit., s. $57-58$. 
Machajski nadał im wspólny tytuł: Pracownik umysłowy. Jeszcze później, bo w 1905 r. tak zatytułowane dzieło ukazało się drukiem w Genewie, zawierając również trzecią część, tj. Socjalistyczna naukę jako nowa religię. Już po zesłaniu w Wilujsku Machajski napisał kolejne prace ${ }^{26}$. Sa one rozwinięciem myśli, poglądów i koncepcji wyłożonych w Pracowniku umysłowym. W Polsce to ostatnie dzieło zostało opublikowane dopiero w $2016 \mathrm{r}^{27}$

Myśli przedstawione w Pracowniku umysłowym świadczą o zasadniczym zwrocie w postawie, w poglądach Machajskiego. Tak jak szybko przestał być wyrazicielem ruchu i koncepcji narodowych, patriotycznych, tak równie szybko odszedł od socjalizmu, od ideologii socjalistycznej. I to jeszcze przed pełną krystalizacją swoich socjalistycznych poglądów - „nie zdażył [...] zostać marksista, kiedy przestał nim już być” ${ }^{28}$. Treść wspomnianych prac Machajskiego w pełni potwierdza taką ocenę.

Prezentowany artykuł nie zawiera pełnego rysu biograficznego Jana Wacława Machajskiego. Nie jest również próba przedstawienia wszystkich poglądów, idei oraz koncepcji tego myśliciela. I jedno, i drugie w stosunkowo krótkim artykule byłoby albo niemożliwe, albo równoznaczne z ogólnikowym, powierzchownym zobrazowaniem sylwetki Machajskiego i jego sposobu myślenia. W rezultacie szczególną uwagę zwrócę na jego poglądy w sprawie socjalizmu, rewolucji społecznej oraz politycznej roli i pozycji inteligencji, tj. tej warstwy społecznej, która w XIX w. miała szczególne znaczenie, przede wszystkim w Europie Wschodniej i Środkowo-Wschodniej, w Rosji i Polsce. Inne poglądy Machajskiego zostaną uwzględnione jedynie $\mathrm{w}$ tym stopniu, w jakim są niezbędne dla analizy głównego zagadnienia niniejszego artykułu. Ostatecznie pominę polemikę Machajskiego z marksowskim schematem reprodukcji i nacisk na wyraźne podobieństwa, zdaniem autora Pracownika umystowego, zasadniczych założeń myśliciela z Trewiru z wcześniejszymi koncepcjami i założeniami Johanna Karla Rodbertusa-Jagetzowa (1805-1875), zwolennika ewolucyjnej drogi do socjalizmu państwowego.

We wszystkich wywodach, także w sprawie inteligencji, wyraźnie widać szczególny stosunek Machajskiego do Karola Marksa i jego teorii. Polski myśliciel posługuje się marksowskimi pojęciami, terminami, kategoriami

${ }^{26}$ Przede wszystkim należy wymienić następujące prace J.W. Machajskiego: Burżuazyjna rewolucja a sprawa robotnicza, [b.m. (Genewa)] 1905; Bilans burżuazyjnej rewolucji rosyjskiej, Genewa (Kraków) 1909, opublikowane w: Anarchizm i anarchiści na ziemiach polskich do 1914 roku, oprac. H. Rappaport, Warszawa 1981, s. 267-284; Religia socjalistyczna a walka robotnicza, w: Anarchizm i anarchiści..., s. 249-267; Robotnik umystowy 1911... Ten ostatni tekst jest bez tytułu, nie ma oznaczonego miejsca powstania. Znajduje się nad nim tylko data, rok 1911, która autor wydania, Lech Dubel włączył do tytułu. Oryginał tekstu jest przechowywany w International Institute of Social History w Amsterdamie, wchodzi w skład zbioru pod nazwą Max Nacht Papers. Pełny wykaz prac J.W. Machajskiego zob. P. Laskowski, op. cit., s. 315-317.

27 J.W. Machajski, Pracownik umystowy...

${ }^{28}$ D. Zych, op. cit., s. 174. 
teoretycznymi, w ludzkich dziejach dostrzega przede wszystkim wyzysk, interesy klasowe i walkę klas. W rezultacie przedstawia w swych pracach marksowska, klasową analizę procesów gospodarczych, społecznych i politycznych. Niemniej dochodzi do wniosków całkowicie sprzecznych z teoriami Marksa, a także innych, w praktyce wszystkich teoretyków socjalistycznych drugiej połowy XIX i początków XX w. W pierwszym rzędzie zarzuca Marksowi niewłaściwe zdiagnozowanie zasadniczego konfliktu w kapitalizmie jako antagonizmu między proletariatem a burżuazją. Uważa, że ta diagnoza jest pochodną innego błędu twórcy Kapitału i jego następców, a więc oceny postępującej polaryzacji społecznej. W tej perspektywie „wielcy kapitaliści” mieliby zwyciężyć „w bezustannej konkurencji drobnych i w ten sposób klasa kapitalistyczna [...] rychło" przeistoczyłaby się „w znikomą garstkę milionerów, całe zaś pozostałe społeczeństwo [...] - w proletariuszy - wyrobników”29. Według zaś Machajskiego istota przemian w Europie była nie polaryzacja, lecz przeciwnie - rozrost „klasy średniej”, „klas średnich”. Polski myśliciel nie zgadza się z późniejsza, uporczywie powtarzaną formuła socjaldemokratyczna, zgodnie z którą klasy wyzyskujące nie moga wzrastać, „bo wszystkie owoce rozwoju przypadaja garstce kapitalistów”. Głosi, że „małe przedsiębiorstwa faktycznie upadaja, ale klasy średnie [...] mimo to rosna”, ${ }^{30}$. Wspólnie z burżuazja, a więc wielkimi posiadaczami kapitału i środków produkcji tworza one „społeczeństwo burżuazyjne”. Pisze, że „rewolucja we Francji z 1848 roku, a konkretnie wydarzenia czerwcowe ${ }^{31}$, ukazała "sprzeczności kapitalizmu» w głębszy sposób niż Manifest Komunistyczny - nie jako antagonizm między kapitalistami a robotnikami, tylko między burżuazyjnym s połeczeńst we m a proletariatem”. To nie tyle „burżuazja”, co „stale rosnace burżuazyjne społeczeńst wo [podkreślenie oryginalne - M.J.Z.]" jest śmiertelnym wrogiem proletariatu $^{32}$. Jako bardzo istotna część klasy średniej inteligencja stanowi równocześnie część społeczeństwa burżuazyjnego.

Należy podkreślić, że inteligencja w ujęciu Machajskiego jest szczególna, specyficzną warstwą społeczna. Odmienną od tej, którą zazwyczaj przedstawiają badacze myśli społecznej XIX stulecia. Zdaniem Andrzeja Walickiego jest ona „grupa względnie autonomiczna, połączona wspólnymi wartościami i poczuciem misji”, typowa „dla krajów zacofanych”, poddanych procesowi „westernizacji” i majacych wystarczająco dużą „ilość ludzi wykształconych, zdolnych do całościowego rozumienia problemów społecznych i do rozwiazywania ich przez krytyczną analizę doświadczeń własnych i cudzych". Inteligencja powstaje w warunkach podważania, zanikania „autorytetu szlachty”

\footnotetext{
${ }^{29}$ J.W. Machajski, Pracownik umystowy..., s. 134; idem, Religia socjalistyczna..., s. 252.

${ }^{30}$ Idem, Pracownik umystowy..., s. 199.

${ }^{31}$ Machajski ma na myśli powstanie robotników w Paryżu w związku z likwidacją tzw. warsztatów narodowych, rozpoczęte 23 VI 1848 r. i krwawo stłumione trzy dni później. M. Żywczyński, Historia powszechna 1789-1870, Warszawa 1967, s. 370-371.

32 J.M. Machajski, Pracownik umystowy..., s. 190, 194.
} 
i „słabości rodzinnego mieszczaństwa” niezdolnego do kierownictwa, do stania się „klasą narodowa”. Jest „międzystanową elitą wykształcenia”, rozwijająca „W sobie poczucie wzmożonej odpowiedzialności za losy społeczeństwa oraz związane z nim ambicje przywódcze. Jeśli zdobywa sukcesy w walce o «rząd dusz» i pielęgnuje w sobie cechy moralnie uzasadniające przywództwo, staje się "inteligencją" w sensie normatywnym - wyraźnie różnym od ujęć opisowych, aksjologicznie neutralnych [podkreślenia oryginalne - M.J.Z.]". W takim ujęciu szczególnie wyrazistymi przedstawicielami normatywnej, etycznej definicji byli rosyjscy narodnicy z lat siedemdziesiąych XIX w ${ }^{33}$

Współczesne Machajskiemu powyższe rozumienie inteligencji często występowało w Polsce. Stefan Żeromski pisał, że polski inteligent „to miłośnik rzeczy publicznej, inspirator obrony wszystkich warstw i klas uciśnionych, altruista, człowiek od tworzenia "programów» skrajnie konserwatywnych i postępowych [...] amator siedzenia za ciemiężonych robotników w Cytadeli warszawskiej" ${ }^{34}$.

W swoich pismach Machajski nie przedstawia własnej definicji inteligencji - dogłębnej i precyzyjnej. To zrozumiałe, bowiem nie był naukowcem, nie prowadził regularnych, systemowych badań tej grupy społecznej ${ }^{35}$. Przyjmuje, że inteligentami sa osoby żyjące z pracy umysłowej, tzw. pracownicy umysłowi; „cała armia pracowników umysłowych” ${ }^{36}$. Używa też takich określeń, jak „wykształcone społeczeństwo”, „wykształcona część społeczeństwa”, „inteligentny proletariat burżuazyjny”, „świat wykształconych”, „świat uczonych ludzi”. Jego ujęcie jest bardzo statyczne, „pracownicy umysłowi” po prostu się pojawiaja $\mathrm{w}$ pewnym okresie procesu dziejowego, ale dlaczego, w wyniku jakich przyczyn - nie wiadomo dokładnie. Nie dostrzegamy u Machajskiego wzmianek w sprawie genezy tej grupy. Pytania, w jakim stopniu była ona postszlachecka, jak w Polsce, a w jakim zaś „międzystanowa”, jak u Walickiego, „elitą społeczeństwa”. Wyraźnie brakuje choćby próby określenia ewolucji czy podziałów w łonie inteligencji.

Machajski dostrzega majątkowe zróżnicowanie „pracowników umysłowych”, ale w istocie przedstawia ich jako zwarta, jednolita grupę społeczna, Nie bierze w ogóle pod uwagę wpływu zróżnicowania dochodów na różnorodne postawy inteligentów, czy to społeczne, czy polityczne. Mówiąc nieco ironicznie, może

\footnotetext{
${ }^{33}$ A. Walicki, O inteligencji, liberalizmach i o Rosji, Kraków 2007, s. 45 . O powstaniu i rozumieniu inteligencji jako grupy społecznej zob. m.in.: M. Janowski, Inteligencja jako kategoria społeczna - fenomen środkowoeuropejski?, w: Cywilizacja europejska, t. III: Różnorodność i podziały, red. M. Koźmiński, Kraków 2014, s. 227 i n.

${ }^{34}$ S. Żeromski, Organizacja inteligencji zawodowej, w: idem, Bicze z piasku. Szkice publicystyczne, Warszawa 1925, s. 54-55.

35 „Pisarz polityczny i zarazem działacz polityczny ma prawo dość intuicyjnie pochodzić do opisu badanego zjawiska. Nie ma sensu stawiać mu wymogu ścisłości formuł naukowych i metodologicznej ścisłości”. L. Dubel, Totalna negacja inteligencji..., s. 70.

36 J.W. Machajski, Pracownik umystowy..., s. 202.
} 
nawet złośliwie, przechodzi do porządku dziennego nad stwierdzeniem, że byt określa świadomość. Nie zauważając pewnej niekonsekwencji, bo generalnie podziela to marksowskie, deterministyczne podejście. Przecież według niego to właśnie materialne i polityczne położenie warunkuje działania „wykształconego społeczeństwa", decydująco wpływa na stan jego świadomości. Wymogi etyczne, altruistyczne idee nie mają tu żadnego znaczenia, liczą się tylko klasowe cele, klasowe interesy inteligentów. Nie czują się oni związani jakimikolwiek zobowiazaniami wobec innych, słabszych grup społecznych. W inteligenckim świecie Machajskiego nie znajdujemy osób obdarzonych przez jego szkolnego przyjaciela cechami siłaczki czy doktora Judyma. Bohaterzy Żeromskiego sa Machajskiemu całkowicie obcy. W jego ujęciu nie pojawia się nic, co wskazywałoby na możliwość choćby najmniejszego przejawu inteligenckiego etosu, inteligenckiego altruizmu. „Pracownicy umysłowi” sa jedynie grupa interesu, wybitnie egoistyczna, identycznie zreszta jak inne, wchodzące w skład społeczeństwa burżuazyjnego, a więc - poza proletariatem, wyraźnie idealizowanym w wywodach Machajskiego. Warstwa pretendująca, aspirująca do wysokiego statusu materialnego oraz władzy. Wykorzystująca, manipulująca teorią i praktyką socjalizmu, zgodnie z przekonaniem, że wszelkie koncepcje, ideologie i działania socjalistyczne, z marksizmem na czele, sa jedynie metoda, „sposobem wybawienia inteligencji” ${ }^{37}$. „Socjaliści tylko po to [...] się narodzili, aby [...] zapewnić syty żywot pasożytów całej wykształconej burżuazji, wszystkim paniczykom inteligentom" ${ }^{38}$. To właśnie ewolucja myśli i praktyki socjalistycznej najlepiej wykazuje, czym jest ta warstwa społeczna, jakie przyświecaja jej cele oraz interesy - rzeczywiste, a nie deklarowane. W rezultacie widoczna, zasadniczą intencją Machajskiego jest demaskacja socjalizmu jako narzędzia politycznego „pracowników umysłowych”, „wykształconego społeczeństwa”. Chęć wykazania zasadności, trafności takiego twierdzenia można dostrzec we wszystkich wywodach polskiego myśliciela.

Jan Wacław Machajski sugeruje, że wyraziciele socjalizmu początkowo „uważali kapitalizm za absolutnie niezdolny do dalszego rozwoju i skazywali go na niechybna śmierc’”39. Niemniej w miarę upływu czasu ich „socjalistyczne plany" ulegały coraz widoczniejszemu ograniczeniu, ,zgodnie z interesami warstw wykształconych”. Wraz z rozwojem „socjalizmu naukowego” postulowane w Manifeście Partii Komunistycznej Marksa i Engelsa zniesienie własności prywatnej zostało ograniczone „do wymogu uspołecznienia samych [...] środków produkcji”, do zniesienia tylko prywatnej własności środków produkcji. „W dzisiejszych czasach - pisze Machajski - marksizm reprezentowany m.in. przez (Karla) Kautsky'ego, nauczającego, że socjalizm wymaga zniesienia własności prywatnej o tyle, o ile wymaga tego oddanie środków

\footnotetext{
${ }^{37}$ Idem, Robotnik umystowy 1911..., s. 110.

${ }^{38}$ Idem, Religia socjalistyczna..., s. 265.

${ }^{39}$ Idem, Robotnik umystowy 1911..., s. 105.
} 
produkcji w ręce społeczeństwa, pozwala swoim adeptom myśleć, co im się podoba” o własności prywatnej w ogóle, w tym „o nietykalnej własności rodzinnej”" Machajskiego. Jego zdaniem odrzucając jedynie prywatną własność ziemi i środków produkcji, marksiści nie sa zbyt oryginalni, bo tylko przejmuja postulat wyrażony przez wspomnianego niemieckiego ekonomistę Rodbertusa-Jagetzowa. Równocześnie socjaliści czy też socjaldemokraci wszystkich w istocie kierunków zaczynają przekonywać, że „dopóki istnieje ustrój kapitalistyczny robotnicy nie moga walczyć o znaczne polepszenie” swej sytuacji, „nie osłabiając organizmu państwowego kraju, a nawet zasad istnienia samego społeczeństwa" ${ }^{41}$.

Wyżej przedstawione zmiany Machajski wiąże z różnymi przyczynami, przede wszystkim z konsekwencjami rewolucji we Francji w 1848 r. Głosi, że „wszystkie do tego czasu istniejące programy socjalistyczne okazały się czczymi marzeniami”. To właśnie wtedy niektórzy socjaliści z Marksem na czele poczęli ratować skompromitowane marzenia socjalistów za pomoca specjalnego naukowego sposobu. „Od dnia dzisiejszego, mówili uczniowie Marksa, tak zwani naukowi socjaliści, którzy urządzili potem wszędzie socjaldemokratyczne partie - robotnicy przestaną błądzić za pustymi mrzonkami utopistów, a pójdą za prawdziwa, nieomylną nauką socjalistyczną. Jeszcze raz został odkryty najpewniejszy, nieomylny i najszybszy sposób wyzwolenia klasy robotniczej" ${ }^{42}$. Ale to właśnie wtedy, konkretnie w czerwcu 1848 r. $^{43}$, okazało się także i to, iż „żądania zabezpieczenia przed głodem wszystkich bezrobotnych, którzy masami przyjechali do Paryża” w zgodzie „z nauką socjalistyczną” w systemie kapitalistycznym są tylko „chimera «bezmyślności»”. Można by je spełnić „w ustroju socjalistycznym”, ale jego urzeczywistnienie „to rzecz o wiele bardziej złożona, niż [...] wydawało się wcześniej”. Niemniej to właśnie ówczesna „chwila historyczna”, a więc rewolucja z 1848 r. „przyniosła przełom w rozwoju socjalizmu. Od tej pory duszy socjalisty nie opuszcza strach przed natarczywością i brakiem rozsądku głodnych mas robotniczych, strach przed żywiołowymi powstałymi robotnikami. Program socjalistów zasadniczo zmienia się" 44 .

Nie bez znaczenia w tym względzie była również ewolucja systemu kapitalistycznego, właśnie po rewolucji z 1848 r. Zdławiwszy pierwotne, skierowane przeciw sobie ataki, „kapitalizm [...] zaczął się rozwijać tak potężnie, że zadziwił cały świat socjalistyczny”. Ugrupowania socjalistyczne stały się wówczas „nadzwyczaj dogodnym parawanem, za którym przystępująca do

\footnotetext{
${ }^{40}$ Idem, Pracownik naukowy..., s. 257, 261.

${ }^{41}$ Idem, Robotnik umystowy $1911 \ldots$, s. 104-105.

${ }^{42}$ Idem, Burżuazyjna rewolucja..., s. 26.

${ }^{43}$ Zob. przypis 32.

44 J.W. Machajski, Robotnik umystowy 1911..., s. 105.
} 
postępu klasa inteligencji i jej obrońcy socjaliści, własnoręcznie wzięli się za rozwój społeczeństwa kapitalistycznego”. Wspomniana klasa rosła i bogaciła się w miarę „rozwoju nowoczesnego przemysłu”, identycznie jak „klasa kapitalistów”. Początkowo „na drodze do swojego szczęścia pańskiego” i należnej sobie, jak uważała, „roli zarządcy” inteligencja dostrzegała „opór magnatów kapitału [...] nowej arystokracji, nieociosanej, zarozumiałej, pijanej ze szczęścia z powodu swojego nieoczekiwanego awansu i bogactwa, gorszej jeszcze pod tym względem od arystokracji staroszlacheckiej”. Niemniej taka sytuacja dosyć szybko zaczynała zanikać, „kapitalizm pierwotnych nieokrzesanych lichwiarzy i zarozumiałych chamów” stopniowo odchodził w przeszłość. Rządząca burżuazja, choć „zwyciężyła socjalistów w rewolucjach”, to dostatecznie wystraszona przez nich „starała się być jak można najszczodrzejszą i najbardziej ustępliwą w stosunku do inteligentów" ${ }^{45}$. Tym bardziej że poziomem i stylem życia, a także wykształcenia obie te grupy w istocie upodobniały się do siebie.

Ostatecznie powstawała sytuacja, w której „kapitalista nikogo nie pozbawia spadku”, przeciwnie, „po bratersku, jak komuniści” dzieli się swoimi bogactwami „z całym światem ludzi wykształconych”, zaspokaja „apetyty komunistyczne inteligentów”, likwiduje „skargi socjalistów, jakoby kapitalizm, uciskając wszystkie klasy, oddał bogactwa całego świata garstce plutokratów”. Jak w dawnych wiekach nowe, kapitalistyczne wcielenie „ustroju grabieżców” zdobywa „zdrowie i potęge” na drodze „poszerzenia sfery rządzących [...] pomnożenia panów i właścicieli”. Uprzednio socjaliści zakładali, że „przemieszczenie bogactw kapitalistycznych do kieszeni pracowników umysłowych" nastapi „dopiero po rewolucji [...] w nowym idealnym społeczeństwie”. Tymczasem dokonuje się ono „bez żadnego przewrotu jeszcze w starym społeczeństwie”. W ten sposób „ustrój burżuazyjny” rozwija i tworzy „ogromną klasę średnią”, czyli inteligencję, i nadaje jej „status pana”. „Kapitalistyczne dążenia inteligencji socjalistycznej sa realizowane w ustroju burżuazyjnym w formie postępu społeczeństwa burżuazyjnego" ${ }^{46}$.

Istotę egzystencji oraz funkcjonowania tego społeczeństwa stanowi wyzysk. Tu Machajski idzie śladem Marksa, ale tylko w pewnym stopniu. Głosi, że „kapitalistyczne społeczeństwo” przygotowuje potrzebną mu ,armię” inteligentów, wykorzystując „szczególny fundusz, «czysty dochód narodowy», czyli ogólna sumę krajowej wartości dodatkowej”. Tym czystym dochodem pochodzacym z wyzysku, a więc z nieopłaconej pracy proletariatu dysponuja „burżuazyjne rodziny dzięki dziedziczeniu własności”. Zdaniem Machajskiego odbierając wykształcenie, a także pobierajac honoraria, pensje za swoja pracę, inteligenci stają się częścią ogólnego, złożonego mechanizmu wyzysku: „na mocy tego, że pochłonęli [...] określoną sumę wartości dodatkowej”, przedstawiciele

${ }^{45}$ Ibidem, s. 104-106.

${ }^{46}$ Ibidem, s. 106-107. 
„inteligentnego proletariatu burżuazyjnego”, „zgodnie z logiką złodziejskiego ustroju” nabywaja „prawo, by [...] odbierać [...] nieodpłatne wytwory cudzej pracy, pracy proletariatu" 47 .

$\mathrm{W}$ rezultacie inteligenci uczestniczą $\mathrm{w}$ procesie grabieży, podobnie jak klasyczna burżuazja, czyli właściciele środków produkcji i kapitału. I podobnie jak ona dziedziczą swoją pozycję materialną. Jak ona są właścicielami stałego dochodu, kapitału przekazywanego z pokolenia na pokolenie. Powstaje inteligencka, dziedziczna własność prywatna, dziedziczna własność osobista, rodzinna ${ }^{48}$. To właśnie dzięki niej „pracownicy umysłowi” są wyłącznymi posiadaczami kapitału umysłowego ${ }^{49}$, to dzięki niej „wielkie bogactwa ludzkości”, czyli wiedza i nauka "stają się dziedzicznym monopolem uprzywilejowanej mniejszości". Przekazując swojemu potomstwu przywłaszczoną w formie wynagrodzenia zapłatę, rzekomo za pracę o „wyższej jakości”, pochodząca z wartości dodatkowej, inteligenci zyskują dziedziczne, wyłączne możliwości zdobywania wykształcenia, co w praktyce przekłada się na identyczna pozycję społeczna, jaką ma burżuazja. I jak ta ostatnia posiadają możliwości spełniania złowieszczej, negatywnej roli społecznej. Zgodnie bowiem z logika wywodu Machajskiego burżuazja jest klasą wyzyskującą dzięki posiadaniu i dziedziczeniu kapitału i środków produkcji, „pracownicy umysłowi” zaś kapitału i wykształcenia. Tak czy inaczej, to właśnie dziedziczne posiadanie decyduje o identycznym statusie tych grup i o ich pozycji wyzyskiwaczy. Zdaniem Machajskiego „pozostałe miliony” również dziedzicza, także maja „dziedziczny monopol”, ale „na niewolnicza pracę własnych rąk”. „Tylko w dziedzicznym kręgu burżuazyjnego monopolu rodzą się talenty, myśliciele, wynalazcy. Po to by dziedziczny monopol mógł «sprawiedliwie» wykorzystywać swoją «indywidualną wiedzę i umiejętności», ograbiono proletariat z dziedzictwa wieków - co więcej, odebrano mu możność normalnego posługiwania się naturalnym organem jakim jest mózg”. „Tylko klasy panujace moga posiadać wiedzę, a nieodłączną istotną cechą niewolnika jest jego ciemnota". Przedstawiciele klas wyzyskujacych sprowadzili poziom życia proletariatu „do minimum środków utrzymania”, by inteligenci „bez żadnych przeszkód sprzedawali «swoje szczególne talenty i umiejętności»". Robotnicy nie moga korzystać z rosnącej wydajności swej pracy, bo ma ona służyć podniesieniu poziomu życia jedynie ,warstw wykształconych" 50 .

Ostatecznie należałoby podkreślić, że według Machajskiego to nie tylko prywatna własność środków produkcji decyduje o wyzysku, jak u Marksa i jego uczniów. U polskiego myśliciela wyzysk pojawia się w wyniku oddziaływania

47 J.W. Machajski, Pracownik umystowy..., s. 202.

${ }^{48}$ Ibidem, s. 131-132, 203; J.W. Machajski, Robotnik umystowy 1911.., s. 75-76.

${ }^{49} \mathrm{~W}$ praktyce wspólnie z przedstawicielami burżuazji. Ci przecież także doceniają wagę wykształcenia i mają środki, by je zdobyć.

50 J.W. Machajski, Pracownik umystowy..., s. 202-203, 256; idem, Robotnik umystowy 1911..., s. 74 . 
przede wszystkim wspomnianej dziedzicznej własności prywatnej, można by powiedzieć - własności prywatnej wyższego rzędu. To ona określa pozycję klas uprzywilejowanych: burżuazji i „pracowników umysłowych”, pozycję materialna, społeczna, polityczną. W ujęciu Machajskiego inteligenci sa „uprzywilejowanymi najemnikami kapitalistycznego państwa”. Podobnie jak przedstawiciele burżuazji, a więc „właściciele kapitału przemysłowego i towarowego”, powołanymi do „zarządzania zarówno w węższym rozumieniu, czyli procesami gospodarczymi”, jak i ogólniej - „całym «życiem narodu»"51.

W takiej perspektywie pojawia się szczególny układ stosunków między inteligencją i proletariatem, a więc grupami tak ważnymi dla teoretyków oraz ideologów wszelkich odłamów socjalizmu. W ujęciu Machajskiego muszą być one antagonistyczne $\mathrm{z}$ racji odmiennego usytuowania ekonomicznego oraz społecznego obu tych grup. Poddana wyzyskowi klasa robotnicza ma zupełnie inne cele oraz interesy niż „pracownicy umysłowi” będący częścia uprzywilejowanego społeczeństwa burżuazyjnego. W rezultacie inteligenci/ socjaliści w każdej sytuacji traktują robotników przedmiotowo. Są oni ważni o tyle, o ile sa przydatni, o ile służą zaspokojeniu interesów inteligentów. $\mathrm{Ci}$ ostatni poniekąd są w stanie pewnej ambiwalencji: wyraźnie chcą wykorzystać robotników w swej polityce, ale równocześnie bardzo dobrze wiedza, że w pewnych sytuacjach robotnicy moga stać się niebezpieczni z punktu widzenia inteligenckich zamysłów. W rezultacie „pracownicy umysłowi” dążą do tego, by posiadać „liczne armie” robotnicze, które z jednej strony zabezpiecza ich „przed «fatalnymi niespodziankami» jak paryskie dni czerwcowe (z 1848 r.)”, a z drugiej - pozwola szantażować, naciskać „na kapitalistów” i wymuszać na nich ustępstwa, poprzez groźbę, że w przeciwnym razie inteligenci/ socjaliści uruchomia swoje „milionowe siły”, wprowadzą „dyktaturę proletariatu”, uzmysławiając „burżujom” potworności, „jakie moga nastapić, gdy tylko socjaldemokracja zrezygnuje z kierownictwa i pozostawi masy same sobie" ${ }^{2}$.

Należy podkreślić, że taka polityka socjalistów stanowi wariant pewnej ogólniejszej tendencji, prawidłowości. Inteligencja jest bowiem kolejna, jedyna z wielu grup uciskanych uciskajacych czy też „wyzyskiwanych wyzyskiwaczy”, jak pisał Max Nacht (Max Nomad) ${ }^{53}$, jeden z niewielu uczniów i zwolenników Machajskiego, streszczając jego poglądy. „Oto podczas każdej rewolucji równocześnie z szerokimi masami ograbionych występowały do boju także

${ }^{51}$ Idem, Pracownik umystowy..., s. 131.

${ }^{52}$ Idem, Robotnik umystowy 1911..., s. 114.

${ }_{53}$ Max Nacht, pseud. Nomad, ur. w Buczaczu na Ukrainie w 1881 r., zm. w 1973 r., od 1913 r. w Stanach Zjednoczonych, wykładowca nauk politycznych i historii na amerykańskich uczelniach. Zob. https://en.wikipedia.org/wiki/Max-Nomad (dostęp: 20 V 2019). Między innymi o jego związkach z Machajskim zob. E. Wilson, Max Nomad and Waclaw Machajski, https://theanarchistlibrary.org/library/edmund-wilson--max-nomad-and-waclawmachajski (dostęp: 23 V 2019). 
niezadowolone warstwy klas uprzywilejowanych, którym istniejąca forma wyzysku nie dawała możności rozwinięcia [...] swych grabieżnych zachcianek, swego pasożytniczego życia”. Ich przedstawiciele stawali na czele uciśnionych, wyzyskiwali nienawiść mas, starali się ukierunkować je na walkę „wyłącznie przeciw tym formom i rodzajom wyzysku, które im były niewygodne, które ich gniotły [...]. I zawsze, gdy pod ciosami zbuntowanych mas zaczęła się chwiać potęga dotychczasowych panów, powtarzała się ta sama historia. Szlachetni oswobodziciele zamieniali się nagle w najdzikszych poskromicieli, którzy jako najbardziej przygotowani do objęcia rządów, czekali tylko na to, by zająć miejsce zwyciężonych panów lub podzielić się z nimi”. Tak postępowała „kapitalistyczna burżuazja” w czasie rewolucji francuskiej po 1789 r., tak czyni obecnie inteligencja, która „wszystkimi siłami” stara się „nienawiść i niezadowolenie mas robotniczych skierować wyłącznie przeciw tym formom ustroju burżuazyjnego, pod którymi cierpi sama [...] wyłącznie przeciw tym instytucjom, które stają na przeszkodzie jej panowaniu [...] zdołała ona wypracować cały system oszukańczych formułek, obłudnych frazesów i zwodniczych obietnic. Wspólnym ich zadaniem: pod nazwą «proletariackiego socjalizmu» powtórzyć w naszych czasach tylekrotnie już w ciagu wieków dokonywane oszustwo" ${ }^{54}$.

Takie instrumentalne wykorzystywanie robotników inteligencja prezentuje szczególnie wtedy, kiedy burżuazja czy też ogólniej: siły starego porządku nie chcą ustępować, nie chcą rezygnować ze swoich przywilejów, gdy zazdrośnie strzega swojego bogactwa i władzy. Idąc za myślą Machajskiego, można by powiedzieć, że to głównie wtedy pojawiaja się swoiste „kłótnie w rodzinie”. „W rodzinie”, bo dotycza proporcji w podziale zysku, wartości dodatkowej, pochodzącej z eksploatacji klasy robotniczej. Ale niekiedy wyraźnie łączą się one z szerszymi celami politycznymi: chęcią obalenia despotycznych monarchii, wprowadzenia demokratycznych swobód, konstytucyjnego porządku, obroną demokracji ${ }^{55}$. A także $\mathrm{z}$ walką o niezależność narodowa. Charakterystyczną cechą tych dążeń jest to, że zawsze je przenika egoistyczny, klasowy interes inteligencji. Szczególnie widać to w monarchii Romanowów. Jak wynika $\mathrm{z}$ wywodów Machajskiego, to w tym państwie inteligencja musi najbardziej walczyć o swoje interesy. Właśnie przy użyciu robotników jako „mięsa armatniego”. Jego uzyskaniu ma służyć fuzja „dwóch

${ }^{54}$ P. Laskowski, op. cit., s. 29-30.

55 J.W. Machajski, Robotnik umystowy 1911..., s. 64. Także za pomoca rewolucji, choć ta burżuazyjna, nieproletariacka rewolucja przyniosłaby „wolność jedynie klasom majętnym: panom upośledzonym i pokrzywdzonym”, dawałaby „pełne prawa wyzysku i pasożytnictwa, dla drobnych właścicieli, dla małych panów” otwierałaby wszelkie drogi do ich wzniesienia i wzbogacenia. Taka rewolucja rozmnażałaby „wyzyskiwaczy ujarzmionych mas [...] pasożytów na ciele ludu robotniczego”, zwiększałaby „cały łup z wyzysku milionów skazanych na dożywotnią niewolniczą pracę”. Nie zmniejszałaby „bynajmniej niewoli robotniczej”, a przeciwnie - wzmacniała i odnawiała. Idem, Burżuazyjna rewolucja..., s. 13. 
pierwiastków - «patriotycznego» i «socjalistycznego»". Powstała w 1892 r. Polska Partia Socjalistyczna (PPS) wchłania ,jawnie nieproletariackie żywioły patriotycznego burżuazyjnego społeczeństwa, a ich potrzeby, marzenia i idee" nazywa „klasowym, proletariackim socjalizmem”. Aktywiści PPS piszą i rozpowszechniają „niezliczone broszury i artykuły na temat raju”, jakim ponoć „okaże się rzeczpospolita polska [...] - nasze, ludu polskiego panowanie [pisownia oryginalna - M.J.Z.]”. W istocie zawierają one oszustwa, bowiem „jak kiedyś szlachta, która wzywała cały naród do walki z despotyzmem o wolność, aby ustanowić bezpośrednią władzę nad zniewolonym chłopem, tak teraz polska burżuazja zaczęła marzyć o odbudowaniu polskiej niepodległości, żeby zyskać wyłączność na użytkowanie bogactw [...], które wytwarza zniewolony proletariusz, żeby panować samodzielnie nad wszystkimi etapami eksploatacji polskiej klasy robotniczej”. „Na użytkowanie bogactw”, a więc „narodowej wartości dodatkowej”, która jak dotąd po części trafia do kieszeni rzeszy rusyfikatorów i carskich urzędników ${ }^{56}$. Chodzi o to, aby ich wykluczyć, pozbawić łupów, które im przypadały. W 1909 r. Machajski ogłosi, że „obydwie partie [tj. PPS i Socjaldemokracja Królestwa Polskiego i Litwy], choć i zapewniaja, że różnią się głęboko w swoich poglądach i hasłach, z jednaka gorliwością wyzyskuja walkę klasy robotniczej na korzyść polskiej inteligencji, polskiej wykształconej burżuazji" ${ }^{57}$. Podobnie postępuja przedstawiciele Ogólnożydowskiego Związku Robotniczego na Litwie, w Polsce i w Rosji (Bund).

Nie zważajac „na rosnacy w szeregach PPS szowinizm, o którym świetnie wiedzą i który tyle razy ich odpychał, właśnie tę partię stawiają sobie za wzór i ida w «polityce» w jej ślady. Zaczynaja bronić interesów «narodu żydowskiego» i walczyć z żydofobami [...]. Domagają się umożliwienia żydowskim klasom średnim (a więc także inteligencji) pięcia się w górę drabiny społecznej uprzywilejowanych, w czym przeszkadza antysemicka polityka samodzierżawia. A żydowski proletariat zapewniaja, że żądanie równych praw obywatelskich dla Żydów wysuwają wyłącznie w interesie proletariatu, dokładnie jak PPS”, która przekonuje, że „«niepodległa Polska» będzie tylko dla proletariatu i tylko przez proletariat wywalczona" ${ }^{58}$.

${ }^{56}$ Idem, Pracownik umystowy..., s. 156, 157, 164, 165.

${ }^{57}$ Idem, Bilans burżuazyjnej rewolucji rosyjskiej..., s. 271-272.

${ }^{58}$ Idem, Pracownik umystowy..., s. 167-168. Mając na uwadze interesy inteligenckie, Machajski w innym miejscu napisze: „Od czasu, jak szlachta zgubiła swoje państwo niepodległe, panowie polscy” muszą dzielić się „skarbami kraju własnego [...] z obcym zaborca [...]. Do wszystkich ważniejszych, a więc i zyskowniejszych posad i urzędów państwowych wykształceni Polacy całkiem dostępu nie maja. Z wielokrotnych i niepomyślnych powstań patrioci polscy wynieśli przekonanie, że droga jedynie narodowej ruchawki jarzma carów moskiewskich obalić niepodobna". Tak więc trzeba odwołać się do proletariatu. Podobnie myślą inteligenci żydowscy. Ile to bowiem „rodzin żydowskich już dawno dzieci swoje w ludzi by wyprowadziło, w prawdziwych panów ich wychowało, gdyby rząd rosyjski nie 
Sytuacja w samej Rosji jest może nieco bardziej skomplikowana, ale $\mathrm{w}$ istocie rozwija się według tego samego wzorca. Klasy średnie, inteligencja, „wykształcona burżuazja” dążą do uzyskania „rzeczywistej wolności, wolności własnego, bezpośredniego i samodzielnego rządzenia państwem, jego skarbem i podległymi mu masami robotniczymi”. Usiłuja obalić „azjatycki system rządzenia i zaprowadzić zachodnioeuropejski”. Niemniej „każda próba w tym kierunku” daje im „przekonanie o własnej niemocy”, jak w czasie i po rewolucji 1905 r. Naturalnym sojusznikiem w tej walce byłby proletariat. Ale od obalenia caratu inteligencja rosyjska bardziej ceni „własne [...] istnienie jako klasy uprzywilejowanej, wolnej od [...] ciężaru pracy fizycznej [...] żyjącej z wyzysku [...] urodzonej dla kierowania pracy niewolników, dla panowania nad nimi”. Przecież buntuje się jedynie po to, „by umocnić i rozszerzyć swoje pańskie panowanie i stanowisko" oraz uzyskać dobra, które wydziera jej „dynastia [...] i cała sfora carskich biurokratów”. W czasie tej walki dopada ją trwoga, by „masy, które sa głodne i ciemne dlatego przecież, że panowie inteligenci zanadto już są syci i oświeceni”, nie zechciały się pozbyć jarzma i dobrać „do kieszeni inteligentów”. Ta „męcząca trwoga przechodzi w rozpacz, w przerażenie”, bo okazuje się, „że głodne, nieszczęsne miliony zdolne sa nawet do pogromów i masowych grabieży”. W rezultacie „miłośnicy wolności składają broń przed potężnym samowładca” i zawierają z nim czasowy, taktyczny sojusz, prowadzący do klęski rewolucji z $1905 \mathrm{r} .{ }^{59}$ Właśnie dlatego, że dążą do wprowadzenia „zachodnioeuropejskiego ustroju”, dbaja oni o to, by samodzierżawie nie zaginęło dopóty, dopóki „głodne masy całej Rosji nie zostana poskromione”. Tak jak przygotowali i przeprowadzili rewolucję „dla wyzwolenia kadetów ${ }^{60}$ i całej wykształconej burżuazji”, tak obecnie „kiełznają «dzicz» rosyjską" do spółki z caratem i kapitalistami. Z wyraźna nadzieją na to, że w przyszłości będzie ją można zamknąć w „konstytucyjnym więzieniu" ${ }^{2}$. Ekonomiczne żądania i wystapienia robotnicze mają być zastapione walką polityczna prowadzoną w imię „burżuazyjnego szczęścia i wolności”. Ostatecznie „inteligenci wszystkich narodowości caratu - rosyjscy, polscy, żydowscy” sprzysięgli się, by robotnicy „walczyli nie za siebie, ale za wykształconą burżuazję”. Zgodnie z socjalistyczną zasada, że „głównym wrogiem robotników jest absolutyzm [...] że powinni (oni) protestować [...]

wzbraniał Żydom dostępu do gimnazjów i uniwersytetów”. Idem, Burżuazyjna rewolucja..., s. 4-5. Oceny Machajskiego, że inteligentom chodzi o dostęp do ważnych i zyskownych „posad i urzędów państwowych”, nie były bezpodstawne. Przekonanie, że „państwo może stworzyć instytucje, w których znajdą zatrudnienie inteligenci”, istotnie występowało i było pożywką „etatyzmu myśli inteligenckiej w II połowie XIX w.” i na początku następnego, XX stulecia. M. Janowski, op. cit., s. 239.

59 J.W. Machajski, Bilans burżuazyjnej rewolucji rosyjskiej..., s. 268-269.

${ }^{60}$ Machajski ma na myśli przedstawicieli Partii Konstytucyjno-Demokratycznej powstałej w Rosji po wydaniu przez cara Mikołaja II manifestu z 17 (30) X 1905 r., zapowiadajacego przyznanie swobód obywatelskich i zwołanie Dumy Ustawodawczej.

61 J.W. Machajski, Bilans burżuazyjnej rewolucji rosyjskiej..., s. 281. 
przeciwko carskim rządom despotycznym [...] stawiać [...] polityczne, a nie ekonomiczne żądania"62.

Zdaniem Machajskiego wyrażający inteligenckie cele i dążenia socjalizm „poczuł nieprzezwyciężoną potrzebę” stania się „prawdziwą nauką społeczna”. Autor Pracownika naukowego ma na myśli przede wszystkim Marksa i Engelsa, twórców „socjalizmu naukowego”, który rzekomo „tak zwycięsko zdruzgotał nauki pierwszych socjalistów-utopistów, pragnacych [...] doprowadzić robotników do przedwczesnego napadu na burżuazję" i równocześnie jakoby zarysował perspektywę poprowadzenia ich „do własnego wyzwolenia”. Machajski pisze, że przedstawiciele „socjalizmu naukowego” coraz widoczniej odchodzą od myśli, by dzieje ludzkie od zarania aż po czasy najnowsze były opisem grabieży i wyrażania „woli panującej mniejszości”. Starają się natomiast uzmysłowić, że można w nich dostrzec obiektywne prawa rozwoju społecznego. Należy je odkrywać i przewidywać, by je wykorzystać dla dobra sprawy robotniczej, dla dobra socjalizmu. Dialektyczny materializm uczy - pisze Machajski - „że po wszystkie czasy, po wszystkie społeczeństwa, wszystkie państwa i ich prawa musiały się stosować do interesów materialnych wszystkich ludzi, do ich potrzeb ekonomicznych, do ich sił wytwórczych"63.

W takiej perspektywie każde zniewolenie znajduje logiczne uzasadnienie: starożytni właściciele niewolników zakuwają ich w kajdany, szlachta chłosta swych poddanych chłopów, kapitaliści zaś morzą robotników głodem jedynie dlatego, że wymagają tego „interesy wszystkich ludzi”, „ekonomiczne potrzeby społeczeństwa”, wszelkie „porządki społeczne”. Istniejący ustrój społeczny jest w pełni uzasadniony, bo „przygotowuje ustrój przyszły, oparty na zupełnej sprawiedliwości i równości”. System kapitalistyczny jawi się tu jako konieczna przesłanka zaistnienia socjalizmu. W rezultacie „po dziśs dzień socjaldemokraci bezczelnie prawią [...] robotnikom za pierwszymi swymi nauczycielami: poczekajcie - «kapitaliści sami sobie grób kopią», "sam bieg rozwoju kapitalistycznego przygotowuje wyzwolenie proletariatu». I to wszystko «niezależnie od woli ludzkiej». Widocznie u socjaldemokratów - ironicznie pisze Machajski - narodziły się nowe, socjalistyczne dobre bogi, które nadziemską swoją władzą poniżą wszystkich silnych i wywyższą słabych"64. Powstają też rozmaite przykazania, przede wszystkim - aby unikać przedwczesnego działania. A to dlatego, że nieudana rewolucja odrzuciłaby robotników „wstecz”, odebrała nawet to, „co już jest zdobyte”. W procesie wyzwalania proletariatu liczy się bowiem nie tyle natychmiastowe pozbawienie burżuazji „zagrabionych bogactw”, co umiejętności urządzenia za ich pomoca „lepszego

\footnotetext{
${ }^{62}$ Ibidem, s. 271, 272. W Rosji „wszyscy socjaliści” dążą „do jednego celu”, tj. do wciagnięcia ludu „do walki o zmianę rządów, do walki ze wspólnym [...] wrogiem, rosyjskim samowładztwem”, starają się „zrekrutować bojowe pułki wśród ludu” do walki z „drapieżnymi rządami carskimi”. J.W. Machajski, Burżuazyjna rewolucja..., s. 7.

${ }^{63}$ Idem, Religia socjalistyczna..., s. 253-254; idem, Pracownik umystowy..., s. 291.

${ }^{64}$ Idem, Religia socjalistyczna..., s. 253.
} 
życia”. To zaś wymaga nauki, oświecenia. Stąd niezliczone „mowy i odezwy [...] książki i gazety”, które „kończą się wiecznie jedną i tą samą śpiewka: wejść zaraz do raju, w ciemnocie waszej, nie jesteście godni. Kształcie tylko i doskonalcie siebie i innych. Inaczej - daremne próby”. A także zawieraja nawoływania: „Nie dojrzał jeszcze owoc! Nie dojrzały jeszcze siły wytwórcze! Nie wybiła jeszcze godzina rewolucji socjalistycznej! Czekajcie!”’5.

Zdaniem Machajskiego takie okrzyki, takie propozycje moga być jedynie świadectwem wyjątkowej perfidii głosicieli „socjalizmu naukowego”. Potraktowane poważnie byłyby zgodne z sugestia, aby robotnicy cała wiedzę potrzebną do kierowania produkcją i życiem społecznym, nabywaną przez inteligentów w toku długoletniej nauki, „w dzieciństwie i młodości”, w szkole i na studiach, uzyskiwali „w godzinach odpoczynku po katorżniczej pracy”, na kursach różnych stowarzyszeń robotniczych... Czyż można by wymyślić „bezczelniejsze naigrawanie się?” Tym bardziej że inteligenccy socjaliści zdaja się proponować rozwiązanie opłacane z cudzej kieszeni i sprzeczne z interesem proletariatu jako całości. A to dlatego, że „świat grabieżców” jest dostatecznie uczciwy - pisze Machajski zjadliwie - by za takie wykształcenie, „samodoskonalenie” płacić częścią wartości dodatkowej, „częścią zysku zdartego z klasy robotniczej". Osoby korzystające z takiej edukacji miałyby szanse „wcisnać się w szeregi uprzywilejowanych”, bo przecież „powszechne $\mathrm{w}$ świecie grabieżców dążenie ludzi do samotnego wdrapywania się na szczyt, najzwyklejsza pogoń za kawałkiem zdobyczy zagarniętej przez właścicieli, to sa ideały obleczone w suknię szlachetnego dążenia uciskanych ku samowyzwoleniu". Ku samowyzwoleniu jednostek kosztem całej klasy robotniczej ${ }^{66}$.

Powyższe sugestie i nawoływania wyrażają logikę postępowania socjalistów. Zwalczaja oni jedynie patologie, zwyrodniałe formy współczesnej cywilizacji, ustroju kapitalistycznego: bezwład gospodarczy, anarchię w produkcji, kryzysy, bezrobocie, groźbę zmniejszenia liczby posiadaczy. Występują przeciwko niemu o tyle, o ile staje on na drodze racjonalnego gospodarowania, postępu, wyzwań współczesności. Nie zwalczają jego istoty, nie przedstawiaja przesłanek usunięcia „trwającego od wieków ustroju opartego na grabieży i przemocy”. „Socjalizm naukowy”, „nauki socjalistyczne” Marksa i jego następców służą jedynie jako środek pozyskania, uwiedzenia szerokich mas. Należy im „wpoić wiarę w nadejście socjalistycznego raju - «niezależne od ludzkiej woli», zarządzone wyrokami historii, wypływające z jej obiektywnych praw". Niemniej jest to jedynie szalbierstwo, tak jak chrześcijaństwo, „które nie buduje królestwa niebieskiego na ziemi, tylko umacnia i uświęca

${ }^{65}$ Ibidem, s. 253, 256-257. W innymi miejscu: „Na zasadzie niby to najgłębszych badań, najzawilszych roztrząsań, najstaranniejszych wyliczeń, marksiści starają się przekonać robotników, że [...] nie nadeszła jeszcze pora dla życia komunistycznego. Ale jeśli poczekać, aż społeczeństwo współczesne dojrzeje do socjalizmu, to nowy porządek tak niezawodnie nastapi, jak dzień następuje po nocy”. J.W. Machajski, Burżuazyjna rewolucja..., s. 26-27.

${ }^{66}$ Idem, Religia socjalistyczna..., s. 266; idem, Robotnik umystowy 1911..., s. 120. 
grabieżny ustrój”. Im bardziej socjalizm stroi się w szaty „nauki”, tym bardziej tworzy „religijne fikcje”, tym bardziej rodzi te same owoce, „co nauki pogańskich kapłanów i chrześcijańskich teologów”67. „Ziemski raj socjalistów jest równie daleki i niedostępny dla żywych ludzi jak i wszelki raj niebiański" przepowiadany przez „klechów”68. W ujęciu Machajskiego nie ma żadnych naukowych praw rozwoju, żadnych możliwości wybudowania zgodnie z nimi doskonałego społeczeństwa przyszłości. Autor Pracownika umysłowego nie wykłada tego expressis verbis, ale daje do zrozumienia, że marksistowskie „nauki” są identycznie prawdziwe jak wywody socjalistów utopijnych. I o tyle gorsze, że przedstawiane z wyraźnie złą wola.

U podstaw „socjalistycznej nauki” leżą same oszustwa. Przede wszystkim „najobrzydliwsze kłamstwa”, że „zysk kapitalistyczny jest już ostatnią możliwą formą wyzysku", że tylko władanie środkami produkcji stwarza możliwości „pasożytniczego życia” i w związku z tym, że przyczyną „wiekowej niewoli mas robotniczych [...] nie jest brak środków do życia, a brak środków produkcji i wynikający z niej system najmu". To właśnie ci, którzy ich nie maja i najmuja się do pracy, sa proletariuszami. Takie teorie zostaja doprowadzone do krańcowości, bo zgodnie z nimi w skład klasy robotniczej nie wchodza „wyłącznie kapitaliści i wielcy posiadacze ziemscy”. Sprawia to, że „zgodnie z niezachwianymi zasadami socjalizmu cała inteligencja należy do klasy wyzyskiwanych, do [...] proletariatu, bo jest zmuszona do sprzedawania swojej pracy «na równi z prostym narodem»" 69 .

W takim rozumieniu proletariat może być jedynie „przerażającą jednościa”. Do tej rzekomej „klasy współczesnych niewolników” należą przecież zupełnie różne osoby: „zarówno inżynier zarządzający fabryka jak i robotnik tej samej fabryki, tzn. zarówno ten, kto mieszka w pałacach, jak i ten, który całe [...] życie spędza w ciężkiej pracy fizycznej i gnieździ się ze swoja rodzina w norze [...] uczony doktor i jego lokaj [...] «panowie» zajmujący komfortowe apartamenty” oraz ich służący, stłoczeni „w kuchni i w śmierdzących komórkach. Jak mogłoby być inaczej? Przecież tacy «panowie» w takiej samej mierze sa pozbawieni środków produkcji jak [...] ich służący”. Ten socjalistyczny „proletariat” wyzyskiwany przez garstkę „magnatów kapitału” ma tyle wspólnego z rzeczywistym proletariatem, co „jednolity, niepodzielny

${ }^{67}$ Idem, Pracownik umystowy..., s. 293, 294, 298, 299.

${ }^{68}$ Idem, Religia socjalistyczna..., s. 267. Żłowski-Machajski: „Nie żywych, dzisiejszych ludzi mają na oku ci nominaliści nowocześni (tj. anarchiści, marksiści, «bolszewiki» i «esery»), lecz swój przyszły «ideał». Sa to religianci nowego świata. Kapłani starego zapewniali swych nędzarzy, że zapłata ich nie jest na tej nędznej ziemi, siedlisku bogaczy, lecz obfita jest $\mathrm{w}$ niebiesiech. Ci kapłani nowego świata zapewniają swych nędzarzy, że zapłata ich jest nie dziś, lecz w "przyszłym ustroju»". S. Żeromski, Nawracanie Judasza. Powieść, Warszawa 1956, s. 58-60.

69 J.W. Machajski, Robotnik umystowy 1911..., s. 74, 76-77; idem, Pracownik umystowy..., s. $196,200,287$. 
naród" w systemie feudalnym z chłopami pańszczyźnianymi. To wraz z nimi $\mathrm{w}$ składzie tego systemu znajdowali się jakoby bogaci mieszczanie, na tej podstawie, że zarówno jedni, jak i drudzy byli pozbawieni przywilejów szlacheckich. Taka „prymitywna a jednak nietykalna teoria socjalistów o inteligencji, w naszych czasach, kiedy inteligencja we wszystkich krajach rośnie pod względem swojego bogactwa i potęgi z taką szybkością - jest po prostu monstrualnie potworna"70. Aby więc zatuszować pasożytnictwo tej grupy, często występuje się z teza, że nie stanowi ona jedności, że rozpada się na różne warstwy, nie ma wspólnej bazy gospodarczej. Wspomina się o „inteligenckim proletariacie”, głównie „w nieszczęsnym imperium rosyjskim, o dyplomowanych inteligentach, biegajacych na lekcje w dziurawych pantoflach, mieszkających w nędzy lekarzach, o inżynierze zmuszonym do pracy jako konduktor tramwaju i najwięcej o głodujących nauczycielach ludowych”. Z intencją udowodnienia, iż „biedujacy inteligenci” rzekomo sa „dowodem na to, że inteligencja nie jest siecią wyzyskiwaczy”. Ale jeśli nie jest, to na tej samej zasadzie „miliony głodujących właścicieli chłopskich i całe masy klepiących biedą majstrów i sklepikarzy” powinny „niezaprzeczalnie świadczyć o tym, że obszarnicy i właściciele kapitału nie stanowią klasy grabieżców". Przecież biedni, drobni producenci i świadczyciele usług również sa „właścicielami narzędzi produkcji i ziemi”. Nie zważając jednakże na takie wewnętrzne zróżnicowanie „burżuazji”, socjaliści przyjmuja, że „posiadanie ziemi i środków produkcji jest podstawą wyzysku we współczesnym świecie”. Tak więc „wystarczy dotknąć ich własnej inteligenckiej skóry”, a wtedy „pracownicy umysłowi” z gorliwością wykorzystuja „,pierwszą nadarzająca się furtkę, aby uciec przed najoczywistszą prawdą [...] że [...] wiedza na równi z ziemią i kapitałem dostarcza środków koniecznych do życia pasożytniczego współczesnym grabieżcom"71.

Ostatecznie Machajski zarzuca socjalistom dzielenie „pracowników umysłowych" na różne warstwy i równocześnie, niezbyt konsekwentnie, zaliczanie ich do jednej grupy, tj. do proletariatu, do „świata pracy”. Pisze, że zgodnie z taka tendencja „w szeregach zapracowanych ludzi” znajduja się wszystkie osoby wykazujace "szczególne zdolności administracyjne czy organizacyjne” i otrzymujące „robotnicza płacę za swoją wysoko kwalifikowana pracę”, chociażby należały „do najwyższych sfer rządzących”. Ironicznie dodaje,

${ }^{70}$ Idem, Robotnik umysłowy 1911..., s. 77. Zagozda-Machajski: „Człowiek w miękkie szaty odziany - to co innego niż człowiek w przepoconej koszuli, w brudnej sukmanie i cuchnacym kożuchu. Mularz z rękoma chropawymi od zeschłego wapna i parlamentarny mówca z atłasowymi dłońmi - to tylko na pozór ta sama falanga ludu. Socjalistyczny poseł do parlamentu, pobierający dziesięć rubli czy guldenów dziennie, i nędzarz ze zdartymi od pracy dłońmi, głosujący posłusznie na parlamentarnego towarzysza - to zabawne kłamstwo towarzyskie”. S. Żeromski, Róża. Dramat niesceniczny, w: idem, Pisma zebrane, t. X, Warszawa 1999, s. 40.

71 J.M. Machajski, Robotnik umystowy 1911..., s. 81-82. 
że wkrótce być może dołączy do nich sam Franciszek Józef, bo austriaccy socjaldemokraci wyrażają opinię, że z marksistowskiego, materialistycznego punktu widzenia „ten ulubiony monarcha” powinien być uważany za „urzędnika państwa”, co stwarza nadzieję, że „po prostu” zostanie zaliczony do „inteligentnego proletariatu” ${ }^{2}$.

Zdaniem polskiego myśliciela w tym socjalistycznym „świecie pracy” $\mathrm{w}$ istocie znajduje się także prawie cała burżuazja. W jego ujęciu nie ma wyraźnej granicy między inteligentami i przedstawicielami bogatego mieszczaństwa. Częstokroć łączą ich podobny stopień wykształcenia, podobne interesy. Niejednokrotnie przedsiębiorcy sa „inteligentami - profesjonalistami”, należą do „świata wykształconych”. Socjaliści występuja tylko przeciw tym, którzy „władają majątkiem wyłącznie na podstawie swoich kapitałów przedsiębiorstwa". Nie maja wykształcenia i kwalifikacji, nie potrafia kierować produkcja i wytwórczością. Sa tylko „drapieżcami”, „lichwiarzami” wzbogaconymi na drodze „spekulacji handlowej”, różnymi „nieociosanymi” typami, „spekulantami giełdowymi”, ,absolutnymi trutniami, nie zajętymi żadną działalnościa”. W społeczeństwie „niepohamowanie dażacym do socjalizmu takich wyrodków zawsze będzie nieznaczna garstka [...] nieznaczna mniejszość”. W rezultacie wrogiem socjalistów jest więc jedynie ta „"garstka szumowin», która pragnie zlikwidować każdy przyzwoity reformator". Socjaliści nie dążą do usunięcia immanentnego zła kapitalizmu, a więc wyzysku i zniewolenia, lecz do tego, by „przywileje kierowania niewolnikami i ich pracą fizyczna” znalazły się w rękach specjalistów i fachowców - „świata wykształconych”. Chodzi o reformę systemu, nie „rewolucję socjalistyczną". Nie jest ona wykluczana, lecz w praktyce odkładana „do dalekich, lepszych czasów”73. Na porządku dziennym są reforma, postęp, demokracja. Ta „postępowa polityka społeczna” może przynieść pewne złagodzenie wyzysku, ale tylko takie, „które tym bardziej go utrwali”. Nie naruszając inteligenckiego monopolu wiedzy, „socjalistyczny ideał” sprowadza się do „"socjalistycznego» podziału dochodu narodowego między ogół warstw wykształconych, armię pracowników umysłowych”. „Wiara w kapitalizm jako warunek końcowy systemu staje się w końcu nieodróżnialna od najszczerszej miłości do burżuazyjnego postępu, do pełni panowania burżuazji [...] nieskrępowanej burżuazyjnej grabieży"; w ramach legalizmu, odrzucania dyktatury, w ramach skłonności do „socjalizmu państwowego". Bez żadnej troski, że w ten właśnie sposób umacnia się „klasę panująca”74.

Machajski nie dostrzega różnic w postawie socjalistów. Nie wytycza granic w zależności od kierunku, jaki reprezentuja. Krytykuje wizje postępu Bernsteina, coraz widoczniejsze w miarę upływu czasu i rozrostu socjaldemokracji.

\footnotetext{
72 Ibidem, s. 94-95.

${ }^{73}$ Ibidem, s. 96-97.

${ }^{74}$ J.M. Machajski, Pracownik umystowy..., s. 203, 265, 291.
} 
Nawiązuje do jego znanego oświadczenia, twierdząc, że „cel ostateczny”, czyli rewolucja wyraźnie się oddala, niknie, rozpływa „w pomroce nadchodzących stuleci”, pozostaje „gdzieś w sferze marzeń o życiu pozagrobowym”. Zgodnie z przekonaniem, że może być on urzeczywistniony tylko „w formie kompromisu" i „we współpracy z coraz to nowymi i [...] szerszymi grupami społecznymi"75. Identycznie myślą i postępują ortodoksi. Czyż któryś z nich „śmiałby odrzucić programowe podstawy rewizjonizmu?” Wyraźnie jest widoczna „marksistowska apoteoza kapitalizmu”. Marksiści głosza, że system kapitalistyczny jest „nieuchronnym stadium” na drodze do socjalizmu, że dotychczasowe niepowodzenia socjalistów sa „oczywistym dowodem nieprzygotowania społeczeństwa do idealnego ustroju", że trzeba nań czekać z cierpliwościa, nie zrywając „niedojrzałego owocu”, bo to groziłoby zniszczeniem „wszelkiej społeczności, zarówno starej jak i nowej”. Takie pouczenia grzebią wszelkie chęci „przewrotu socjalistycznego”, skupiają nadzieję „na rozwoju kapitalizmu, na postępie społeczeństwa burżuazyjnego”. W praktyce więc socjalizm jest i dla marksistów równoznaczny właśnie „z postępem burżuazyjnym”, z systemem „określonych dążeń realizowanych w starym świecie”, z określoną tendencja „,w rozwoju współczesnego (kapitalistycznego)

75 Ibidem, s. 96, 127. Machajski ma tu na myśli najsłynniejszą bodajże myśl Bernsteina: „dla tego, co rozumie się zwykle przez ostateczny cel socjalizmu, mam nadzwyczaj mało zrozumienia i zainteresowania. Cel ten jakikolwiek by nie był, jest dla mnie niczym, ruch wszystkim. A przez ruch rozumiem i ogólny ruch społeczeństwa, tj. postęp społeczny i polityczną oraz gospodarczą agitację i organizację dla spowodowania tego postępu". E. Bernstein, Der Kampf der Sozialdemokratie und die Revolution der Gesellschaft, „Die Neue Zeit” 1897-1898, Jg. 16, Bd. 1 (1898), H. 18, s. 556, cyt. za: P. Laskowski, op. cit., s. 96, przypis 7. Bardzo rzadko jednakże się pamięta, że jeden z „klasyków” marksizmu, tj. Fryderyk Engels, na krótko przed swoja śmiercią w 1895 r. przyznawał, że wieszczone przezeń wraz z Marksem przewroty rewolucyjne moga w ogóle nie nastapić i socjalizm zamiast „na barykadach” zwycięży „przy urnie wyborczej”, co niewątpliwie było zgodne z późniejszymi, ogólnymi, rewizjonistycznymi zasadami zachodnich socjaldemokratów spod znaku Bernsteina. Engels pisał, że „rebelia w dawnym stylu, walka uliczna z barykadami, która aż do roku 1848 była wszędzie środkiem ostatecznie rozstrzygającym, jest już w znacznym stopniu przestarzała [...]. Ironia historii przewraca wszystko do góry nogami. My «rewolucjoniści», "wywrotowcy» rozwijamy się lepiej za pomocą środków legalnych niż za pomocą środków nielegalnych i przewrotu". Te stwierdzenia po raz pierwszy zostały opublikowane w nieco okrojonej wersji w „Die Neue Zeit”, nr 27 i 28 za lata 1894-1895. Pełny tekst: F. Engels, Wstep do pracy Karola Marksa Walki klasowe we Francji 1848-1850 (wyd. z 1895), w: K. Marks, F. Engels, Dzieła, t. VII, Warszawa 1963, s. 612, 615, 617, cyt. za: R. Pipes, Piotr Struwe..., s. 189-190. Ze swej strony Pipes trafnie wykazuje, że powyższa stwierdzenia Engelsa „można uznać za inicjujące rewizjonizm w węższym i historycznie precyzyjnym sensie tego słowa”. R. Pipes, Piotr Struwe..., s. 190. Paradoksalnie więc to współtwórca marksizmu, a nie Bernstein byłby właściwym inicjatorem rewizjonizmu. Zob. też: R. Pipes, Rewolucja rosyjska, tłum. T. Szafar, Warszawa 1994, s. 275; P. Laskowski, op. cit., s. 26. Stwierdzenia Engelsa i ocena Pipesa w jakiejś mierze współgrają z krytyką marksistów przedstawiona przez Machajskiego, zarzucającego im oportunizm, poniechanie walki z kapitalizmem i burżuazja, rosnący kult postępu, reformy i demokracji. 
ustroju”. Ostatecznie marksiści sa „komunistami” łaknącymi socjalizmu, ale jako „kontynuacji rozwoju kapitalizmu”"

W ujęciu Machajskiego marksiści, do których w zgodzie z logika jego wywodów w istocie należałoby zaliczyć także rewizjonistów, osiagnęli i zachowali ogromne wpływy, a to dlatego, że w porównaniu z innymi, „starymi szkołami socjalistycznymi” najlepiej potrafili bronić interesów „pracowników umysłowych”. Twierdząc, że „kapitalizm nie tylko nie ograbia, ale też pełni misję historyczna”, akceptowali oni w istocie „drapieżczy” ustrój kapitalistyczny ${ }^{77}$. Ale i teoretyczne przejście do socjalizmu nie znosiłoby „wielowiekowej grabieży” i niewoli. Likwidacja prywatnej własności środków produkcji byłaby przecież równoznaczna tylko ze zniesieniem kapitalistycznego wyzysku. „Kapitały prywatne” zostałyby zastapione przez „kapitał narodowy”. Powstałoby nowe, „demokratyczne państwo-społeczeństwo” dysponujące wszelką własnościa, wszelkimi środkami produkcji, spełniajace rolę nowego powiernika, nowego dysponenta kapitału, sowicie opłacające „pasożytniczą egzystencję wszystkich grabieżców, całego burżuazyjnego społeczeństwa”. Nastapiłaby więc swoista dyslokacja kapitału, z rak prywatnych w społeczne, ale istota rzeczy nie uległaby zmianie. Robotnicze płace byłyby utrzymane „na poziomie minimum niezbędnego do zachowania przy życiu siły roboczej”, inteligenckie „pasożyty” zaś nadal żyłyby z wartości dodatkowej, z dochodu narodowego rosnacego w miarę upływu czasu, wraz z postępem technicznym. Dochodu, „który dzięki własności rodzinnej i rodzinnemu porządkowi społecznemu chroniony jest i reprodukowany w następnym pokoleniu" "78.

W tych warunkach naiwne i utopijne są mniemania, by inteligencja żyjąca z wyzysku i wpisujacca swoje prawa „w ramy ustroju klasowego" rzeczywiście mogła być siłą rewolucyjną walcząca o wyzwolenie robotników. Przecież „warstwy wykształcone nie rodzą się inaczej niż jako grupa uprzywilejowana, a pierwszą "usługą" jaką świadczą społeczeństwu, jest konsumowanie dochodu narodowego”. Nie moga więc pełnić funkcji „zbawców”, „apostołów swobody”. Mogą być tylko „ciemiężcą mas robotniczych”. Zgodnie z faktem, że prawdziwym, najważniejszym celem „współczesnego socjalizmu” jest „wyniesienie jednej części swojego "proletariatu», to jest inteligencji, do statusu klasy panujacej, a następnie osadzenie na plecach robotników nowych, świetnie rozmnażających się pasożytów"79. Walczą oni o demokrację, ale jak wykazały dzieje rewolucji we Francji w 1848 r., następnie krwawo tłumią wystapienia robotników; nie gorzej „od wszystkich ekspedycji rosyjskiego samowładcy” Inteligencja u władzy zazwyczaj jest siłą opresyjną.

\footnotetext{
76 J.W. Machajski, Pracownik umysłowy..., s. 97; idem, Robotnik umystowy 1911..., s. 109-111, $114,115$.

${ }^{77}$ Idem, Robotnik umystowy 1911..., s. 110.

${ }^{78}$ Idem, Pracownik umystowy..., s. 262-263, 290.

${ }^{79}$ Ibidem, s. 270, 279, 280; J.W. Machajski, Robotnik umystowy 1911..., s. 117.

${ }^{80}$ Idem, Pracownik umystowy..., s. 133-134; idem, Religia socjalistyczna..., s. 264.
} 
Wyraźny pesymizm widać także w wypowiedziach Machajskiego poświęconych anarchistom. Polski myśliciel głosi, że ich „recepty” sa całkowicie nieprzydatne. Przecież samowystarczalnym społecznościom, „słynnym “wolnym komunom»" anarchistów, zastępujacym państwo i jego organy także będą potrzebni „wykształceni specjaliści”, a więc w praktyce inteligenckie „pasożyty”. Bez nich nie ruszy przecież jakakolwiek produkcja wymagająca utrzymania na poziomie zgodnym „z najnowszymi wymogami techniki”. Również postulowany przez anarchistów „całkowity i bezwzględny federalizm” nie rozwiąuje problemu. Federacyjne ustroje Stanów Zjednoczonych i Szwajcarii świadczą bowiem, że „burżuazja wynalazła (taki) system państwowy”, który zapewnia jej „władzę nie mniej silna, niż najbardziej scentralizowane państwa na świecie". W rezultacie ponieważ państwa są instrumentem ucisku i wyzysku klas posiadających, można by je zlikwidować tylko poprzez „wywłaszczenie wszystkich właścicieli”"1. Zdaniem Machajskiego błędne są również poglądy tych myślicieli, którzy jak Piotr Kropotkin dostrzegają podział „na dwie antagonistyczne grupy”: „lud” postępujący zgodnie z ideałami równości i „władza”, „która opanowała społeczeństwo” i psuje „tę dobra robotę”. Wyraźnie oni przeceniaja skłonności ludzi do kooperacji i solidarności oraz błędnie głosza, że przemoc, grabież i wyzysk sa jedynie „przypadkowa, omyłkową manifestacją drugiej strony ich duszy”. Anarchiści nie widza, że „cywilizowane społeczeństwa” są „więzieniami niewolników” i postrzegaja je „,jako owoce współpracy”. Opowiadaja „bajeczki o tym, że celem każdej instytucji jest zaspokojenie potrzeb w naszym cywilizowanym społeczeństwie”. „Uczą niewolników, by nie rwali łańcuchów, tylko uśpili się ich snem" $"$.

W ujęciu Machajskiego całe dzieje ludzkie są dziejami „cywilizowanych społeczeństw”, wiekami budujących „więzienia dla niewolników”83. Głosi on, że grabież, niewola i wyzysk występują od zarania dziejów, że zmieniaja się tylko klasy wyzyskujacce i wyzyskiwane oraz formy wyzysku. Kolejno pojawiają się właściciele niewolników i niewolnicy, „średniowieczni rycerze” i pańszczyźniani chłopi, kapitaliści i robotnicy. Podobnie jak „wszelkie inne bogactwa”, ci pierwsi, a więc „właściciele cywilizacji” zawsze posiadają monopol wiedzy, niezależnie od kolejnych „przewrotów społecznych”. Zazdrośnie strzega swych tajemnic, można by powiedzieć - identycznie jak egipscy kapłani w znakomitej powieści Bolesława Prusa. W tej perspektywie uprzywilejowani „pracownicy umysłowi” w ustroju kapitalistycznym sa jedynie ogniwem w łańcuchu historii. Osobami doprowadzajacymi do perfekcji metody skrywania „istoty i źródła” ucisku i wyzysku. Metody powstające w rezultacie odwołania się „grabieżców” do „praw naturalnych, do praw przyrody”.

\footnotetext{
${ }^{81}$ Idem, Robotnik umystowy $1911 \ldots$, s. 84-85.

82 Idem, Pracownik umystowy..., s. 302, 309-311, 313.

${ }^{83}$ Ibidem, s. 312.
} 
Ich przestrzeganie rzekomo ma być warunkiem „powszechnego dobrobytu”. „Właściciele świata” przedstawiaja „niewolę” jako współpracę „zarysowana przez samą naturę", a narzędzia ucisku - jako naturalne ogniwa „społecznego organizmu rozwijającego się zgodnie z nieprzezwyciężonymi prawami przyrody". W ten sposób socjaliści, a zwłaszcza marksiści popularyzują teorię, że „niewola i ucisk, grabież i wyzysk” sa „niepojętymi drogami opatrzności”, wiodącymi „ludzkość ku przyszłemu braterskiemu współżyciu”. W ich wywodach nie ma miejsca na rozróżnienie między pracą fizyczną i umysłowa, na żadne antagonizmy. Jest tylko „szalbierstwo”, „sztuczka socjologiczna” umożliwiająca uświęcenie „grabieżczego «podziału pracy»”, ukrycie rzekomego „harmonijnego połączenia pracy fizycznej z umysłową. Nieznoszące, choć zaciemniające i zmniejszające najbardziej niehumanitarne formy wyzysku i ucisku; dawni pańszczyźniani chłopi otrzymuja wolność, „bo stało się oczywiste”, że właśnie jako „"wolni obywatele» pod groźbą głodowej śmierci lepiej będą wykonywać swoją niewolniczą pracę"84. W rezultacie - pisze Machajski - można darować niewolnikom zarówno „wolność polityczna”, jak i „całkowity samorząd”, „bez najmniejszego niebezpieczeństwa dla grabieżców”. Te ustępstwa sa pozorne, ponieważ utrzymana zostaje, a nawet doprowadzona „do perfekcji” podstawowa zasada funkcjonowania każdego „cywilizowanego społeczeństwa”. Społeczeństwa, w których „jedynym celem produkcji” jest nieograniczona „pasożytnicza konsumpcja klas panujących”. Podporządkowani im „niewolnicy” otrzymują jedynie minimalna, „najniezbędniejszą karmę” do przeżycia $^{85}$. Faktycznie nie uczestniczą więc $\mathrm{w}$ podziale rosnącego przychodu gospodarczego.

Ostatecznie socjaliści, czyli „pracownicy umysłowi” dominuja „przy pomocy "cywilizowanego» szalbierstwa" i z obawy, by robotnicy nie uzyskali „możliwie najwyższej płacy za swoją niewolniczą pracę fizyczną", odkładaja „rewolucję robotnicza”, „przewrót społeczny” do „lepszych czasów”, $\mathrm{w}$ istocie - ad calendas graecas. Im bardziej rosna w siły, tym bardziej się oddalaja, by użyć języka Bernsteina, „od obiecanego "końcowego celu»”. Co innego mówia, a co innego robia. Walczą o własne, inteligenckie cele klasowe, a występują z frazesami o „dobru całej ludzkości”, o „najdoskonalszym raju”. Niby wyrażają dążenie do ideału, bo przecież „bez ideałów nie można żyć na świecie”. Nie ma społeczeństwa pozbawionego ideałów, ale $\mathrm{w}$ ujęciu socjalistów służą one jedynie ogłupianiu robotników. W istocie sa tym, „czym gwiazda polarna dla marynarzy; spojrzenia zawsze powinny być skierowane na nia, ale pragnienie osiagnięcia jej byłoby głupotą". Socjaliści głoszą więc, że materialne, duchowe, intelektualne siły ludzkie na razie sa zbyt watłe, zbyt małe, by urzeczywistnić te wzniosłe, szlachetne cele, ideały. Obecnie należy się rozwijać, samodoskonalić. Jest to „diabelskim

${ }^{84}$ J.W. Machajski, Robotnik umystowy 1911..., s. 92-93, 98, 100-101.

${ }^{85}$ Ibidem, s. 93; J.W. Machajski, Pracownik umystowy..., s. 278, 319. 
szyderstwem ze zniewolonych”, wykazywaniem im, że co prawda „ręce i nogi macie związane, ale musicie, nie gubiąc drogi, nauczyć się chodzić jak ludzie wolni" ${ }^{\circ 6}$.

W tych warunkach robotnicy muszą aktywnie walczyć o swoje prawa. $\mathrm{Z}$ tym tylko, że nie „w istniejących organizacjach robotniczych, choćby wielomilionowych”. Głównie dlatego, że sa one legalne, a więc „istnieją o tyle tylko i dopóty, dopóki wyrzekają się natychmiastowej rewolucji [...] i szanują [...] «porządek państwowy»". Po wyjściu poza ramy legalności władze przeciw nim wystapia, nawet te najbardziej demokratyczne, jak francuskie z socjalistycznymi ministrami na czele ${ }^{87}$. Robotnicy mogą osiagnąć swoje cele wyłącznie na drodze ogólnego, gwałtownego, wszechświatowego przewrotu. Dokonanego za pomoca sprzysiężenia, organizacji bojowej, umowy robotniczej; tajnego, powszechnego spisku dążącego do „przekształcenia tak często wybuchających i tak burzliwych strajków w powstanie, w ogólnoświatową robotniczą rewolucję". Będzie ona rzeczywistą rewolucja proletariacką przynosząca, jak niegdyś pisali „klasycy” w Manifeście Partii Komunistycznej, „despotyczne wtargnięcie proletariatu w prawo własności”, równoznaczne ze zniesieniem nie tylko prywatnej własności środków produkcji, ale ogólniej - dziedzicznej własności prywatnej. Umożliwi to robotnikom osiagnięcie „najwyższej płacy zarobkowej”, a także zrównanie ich dochodów z inteligenckimi. Odrzucone zostana ,jako jedno wielkie kłamstwo wszystkie brednie socjalistyczne o wychowaniu mas dla życia przyszłego". W rezultacie upadnie społeczeństwo burżuazyjne, znikną mechanizmy zniewolenia i wyzysku. Mając identyczne płace, wszyscy ludzie „staną się jednakowo inteligentnymi [...] nie będzie kogo skazywać na [...] katorgę dożywotniej pracy fizycznej, nie będzie można nikogo ograbiać"88.

Taka rewolucja zostanie przeprowadzona bez udziału inteligencji i przeciw inteligencji, istotnej części społeczeństwa burżuazyjnego. W koncepcji Machajskiego odrzucenie każdej formy socjalizmu jest koniecznym, niezbędnym warunkiem powodzenia robotniczego przewrotu. W zgodzie z przekonaniem, że odebranie własności jedynie małej grupie kapitalistów i wielkich właścicieli ziemskich, tj. burżuazji, nie przyniosłoby całkowitego wywłaszczenia umożliwiającego rzeczywiste wyzwolenie proletariatu. Wiedza to robotnicy, wiedza ich „rzekomi sojusznicy”, tj. „pracownicy umysłowi”. Świadomi, „że kiedy proletariat weźmie się za wywłaszczanie burżuazji”, to następni w procesie pozbawiania własności będą oni, inteligenci. Nic więc dziwnego, że jak tylko

${ }^{86}$ Idem, Robotnik umystowy 1911..., s. 116-120.

${ }^{87}$ Machajski ma na myśli „proletariuszy”, „towarzyszy” „Millerandów”, jak się wyraża ironicznie. Idem, Pracownik umystowy..., s. 254. Minister handlu, przemysłu i poczty w latach 1899-1902, Alexandre Millerand (1859-1943) jako pierwszy socjalista zapoczątkował współpracę w zarządzaniu państwem (francuskim) z partiami „burżuazyjnymi”.

88 J.W. Machajski, Pracownik umystowy..., s. 132, 292, 298; idem, Robotnik umystowy 1911..., s. 66; idem, Religia socjalistyczna..., s. 261-263. 
moga, uniemożliwiają robotnikom „wszczęcie przygotowań do tego dzieła”" zasadnicze, obiektywne różnice interesów przeciwstawiają „pracowników umysłowych" klasie robotniczej.

Bardzo łatwo można dostrzec błędy w rozumowaniu Machajskiego. Nieporozumieniem wydaje się jego zasadnicza teza, że główną przesłanką ewolucji teorii i praktyki socjalizmu było uwzględnianie rosnących, materialnych potrzeb inteligencji. Nie należy lekceważyć oddziaływania tego czynnika, ale podstawowa przyczyna ewolucji socjalizmu leżała gdzie indziej. Wynikała z faktu, że rozwój technologii i gospodarki, i co za tym idzie rosnące dochody, łagodziły, choć nie likwidowały przejawów i niemałych obszarów nędzy czy niedostatku. Korzystne zaś przekształcenia polityczne, dające prawa wyborcze coraz liczniejszym grupom społecznym, siłą rzeczy sprzyjały przekonaniu, że wpływ czy udział we władzy będzie umożliwiać poprawę materialnego położenia proletariatu i szerzej - świata pracy najemnej. Wszystkie te czynniki musieli brać pod uwagę teoretycy, ideologowie i przywódcy partii socjalistycznych i socjaldemokratycznych. W rezultacie tezy o immanentnym jakoby kapitalistycznym wyzysku schodziły na dalszy plan, zwyciężały zaś koncepcje rewizjonistyczne i reformistyczne, związane z praktycznymi, a nie wydumanymi korzyściami, osiaganymi ponoć po zwycięskiej rewolucji, przedstawianymi m.in. przez Machajskiego. Wspomniane koncepcje znajdowały uznanie także robotników rosyjskich, co wzbudzało zaniepokojenie Władimira I. Lenina. Ważne jest także to, że aspiracje i motywacje robotnicze nie musiały sprowadzać się tylko do spraw bytowych. W ujęciu Machajskiego wszelkie inne kwestie, np. polskie aspiracje niepodległościowe, sa zgodne jedynie z interesami „pracowników umysłowych”. Jeśli robotnicy je popieraja, to wyłącznie jako powolne i bezwolne narzędzia przedstawicieli tej właśnie grupy społecznej. Machajski krytykuje narzucanie robotnikom inteligenckiego rozumienia ich interesów, ale sam właściwie postępuje identycznie; również wie najlepiej, jakie są interesy proletariatu. Co najważniejsze, jego wizja rewolucji to czysta utopia i jako taka zawiera przeciwstawienie świata idealnego, doskonałego istniejącemu bytowi ludzkiemu skażonemu różnymi ułomnościami i niesprawiedliwościami. Autor Pracownika umystowego przebywa w świecie abstrakcyjnych pojęć, nie bada ich odniesienia do rzeczywistości, do tego, czy sa one przyswajane przez robotników, do których sa przecież adresowane. Nie pyta się, czy jego wszechświatowa rewolucja proletariacka istotnie jest możliwa, czy robotnicy do niej dąża, czy pragną głównie dostępu do wiedzy i wykształcenia jako warunku własnego wyzwolenia. Nie zastanawia się, czy może nie ważniejsze są dla nich rosnące zarobki osiagane w istniejącym ustroju generującym, jak uważa, jedynie zniewolenie i wyzysk. Ale czy aby istotnie tylko te zjawiska? Czy system kapitalistyczny wyklucza rzeczywiste polepszenie materialnego bytu klasy robotniczej? Przyszłość miała wykazać,

${ }^{89}$ Idem, Pracownik umystowy..., s. 204. 
że jest ono możliwe. Machajski mógł tego nie wiedzieć, co by jednakże świadczyło jedynie o tym, że w powyższej sprawie okazał się słabym futurologiem. Nie przewidział, że robotnicy będą otrzymywać nie tylko - jak pisze - „najniezbędniejsza karmę"90.

Bardzo naiwne wydaja się dzisiaj wywody Machajskiego w sprawie „urawniłowki" - wyrównania płac robotniczych i inteligenckich; na jakim poziomie i kto miałby o tym decydować? Podobnie jak niewypowiedziane, ale wyraźnie widoczne $\mathrm{w}$ logice rozważań polskiego myśliciela założenie o możliwości istnienia społeczeństw pozbawionych elit. Przechodzi on do porządku dziennego nad tym, że wyrównane szanse edukacyjne proletariatu i „pracowników umysłowych", powstałe - jak głosi - w wyniku zniesienia dziedzicznej własności prywatnej oraz identycznego poziomu zarobków, nie zlikwidowałyby przecież mechanicznie „katorgi” pracy fizycznej. Dopóki jest ona konieczna, to w każdej społeczności musi występować podział na pracowników fizycznych i umysłowych. $\mathrm{Ci}$ ostatni siłą rzeczy znajduja się w lepszej sytuacji. Obejmuja stanowiska wymagające specjalistycznego wykształcenia, sprawują funkcje kierownicze, sa wyposażeni w moce decyzyjne. Ostatecznie społeczny podział pracy niechybnie musi prowadzić do zróżnicowania społecznego i powstawania elit.

Wszystkie te fakty wydaja się oczywiste, ale jedynie wtedy, kiedy punktem odniesienia jest rzeczywistość; „niedoskonałe społeczeństwo”, jak by napisał Milovan Đilas ${ }^{91}$. Jedyne, jakie może istnieć. Reformowalne, ale zawsze dalekie od ideału, od doskonałego, harmonijnego świata, od „królestwa niebieskiego na ziemi”, a więc od tego, jak sugeruje Machajski, co nie udało się chrześcijaństwu. Zdaniem Żeromskiego autor Pracownika umysłowego jest idealista, który „zupełnie nie wierzy w potęgę ciemnoty”. Snuje wizje, „że nakarmiony lud sam urządzi swe życie w sposób doskonały, według tych idealnych wzorów, jakie widzą oczy marzyciela społecznego". W jego teorii wszystko ,jest czyste i dobre, jak człowiek, który ją wymyślił, lecz dalekie od życia [...]. Gdyby żył w średniowieczu założyłby zakon lub sektę religijną. Dziś założył sektę społeczną" ${ }^{2}$.

${ }^{90} \mathrm{~W}$ rezultacie rzeczywistego rozwoju gospodarczego w okresie tzw. złotego wieku kapitalizmu, tj. od czasu zakończenia II wojny światowej po połowę lat siedemdziesiątych XX w. Zob. E. Hobsbawm, Wiek skrajności. Spojrzenie na Krótkie Dwudzieste Stulecie, tłum. M. Król, J. Kalinowska-Król, Warszawa 1999, s. 241 i n.; T. Judt, Powojnie. Historia Europy od roku 1945, tłum. R. Bartołd, Poznań 2008, s. 383 i n.; J. Fourastié, Les trente glorieuses: oula révolution invisible de 1946 à 1975, Paris 1979. Niewątpliwej poprawie materialnego położenia świata pracy najemnej sprzyjały koncepcje wybitnego ekonomisty brytyjskiego Johna Maynarda Keynesa. Przedstawione w połowie lat trzydziestych XX w., a zastosowane w praktyce po zakończeniu II wojny światowej, zakładały potrzebę zwiększenia popytu przyspieszającego tempo wzrostu gospodarczego i likwidację bezrobocia. J.M. Keynes, The General Theory of Employment, Interest and Money, New York 1935, wyd. pol.: Ogólna teoria zatrudnienia, procentu i pieniqdza, tłum. M. Kalecki, S. Raczkowski, Warszawa 1956.

${ }_{91}$ Zob. M. Djilas, The Unperfect Society. Beyond the New Class, New York 1973; M.J. Zacharias, Idee, utopie, rzeczywistość..., s. 221-256.

${ }^{92}$ S. Żeromski, W sprawie Machajskiego (1911)..., s. nlb. 
Należałoby jednakże podkreślić, że błędne byłoby postrzeganie Machajskiego jedynie jako uduchowionego idealistę, jeszcze jednego utopistę niedostrzegającego rzeczywistych mechanizmów społecznych i politycznych, kierujacego się jedynie wyimaginowanymi pomysłami, przemyśleniami i kalkulacjami. W jego myśli bowiem były widoczne również trafne i racjonalne oceny, wnioski i ustalenia. Dotyczyły one m.in. znaczenia, jakie wiąże z wiedza. Wykształcenie niewątpliwie nie było podstawową przyczyną uprzywilejowanej pozycji społecznej. Ale z drugiej strony nie należy zapominać, że np. w Europie Zachodniej większość dzieci jeszcze w latach pięćdziesiątych XX stulecia kończyła jedynie szkołe podstawowa, w wieku 12-14 lat. „Wykształcenie średnie wciąż było przywilejem klas średniej i wyższej”, osiagali je nieliczni93 ${ }^{93}$. Taka sytuacja co najmniej utrudniała awans młodzieży pozbawionej edukacji, petryfikowała jej upośledzoną rolę i poniżające w istocie położenie, a także ogólną sytuację społeczną umożliwiającą dominację klas posiadających. Bariery wykształcenia wyraźnie przyczyniały się do petryfikacji istniejących barier społecznych. I odwrotnie, zgodnie z zasadą sprzężenia zwrotnego bariery społeczne umacniały ekskluzywne systemy kształcenia. W tym sensie niewątpliwie należałoby przyznać Machajskiemu rację.

W dużym stopniu trafne są także analizy polskiego myśliciela dotyczące kapitału, a co za tym idzie, podobnego, jeśli nie identycznego statusu materialnego i społecznego: burżuazji oraz inteligencji. W tym ostatnim wypadku należałoby oczywiście dodać, że chodzi o tę część „pracowników umysłowych”, którzy rzeczywiście osiagali wysokie czy bardzo wysokie dochody. Machajskiemu trzeba by przyznać rację również wtedy, gdy przeciwstawia liczebny wzrost klas średnich, w tym inteligencji, marksowskiej polaryzacji, rzekomo w związu z procesem nieuchronnego podziału społeczeństwa na coraz mniejszą liczbę kapitalistów i rosnącą proletariatu, pogrążonego w coraz większej nędzy ${ }^{94}$. A także gdy zwraca uwagę na specyficzne interesy inteligencji oraz jej skłonności do instrumentalnego traktowania robotników czy szerzej warstw upośledzonych. Taka sytuacja uwidoczniła się przecież w przypadku chłopów i narodnickiej, rewolucyjnej młodzieży inteligenckiej, robotników i bolszewickiego kierownictwa z Leninem na czele, a w Polsce - w związku z postawą Józefa Piłsudskiego wysiadającego „z czerwonego tramwaju na przystanku niepodległość" oraz dawnych, inteligenckich przywódców opozycji po przemianach zapoczątkowanych w 1989 r. $^{95}$

${ }_{93}$ T. Judt, op. cit., s. 462.

${ }^{94}$ K. Marks, Capital. A. Critical Analysis of Capitalist Production, t. I, London 1887, s. 836-837, cyt. za: B. Russell, Wiek XIX, tłum. A. Pański, Oświęcim 2018, s. 204 (tytuł oryg. Freedom and Organization 1814-1914, London 1934). Zob. też: L. Kołakowski, Gtówne nurty marksizmu, t. I, Warszawa 2009, s. 300-301, 376-377.

95 Szczegóły zob. M.J. Zacharias, Putevi i bespuća revolucionarne misli..., s. 363-366; idem, Intelligentsia and New Class..., s. 172-175. Tu, jak myślę, należałoby przytoczyć refleksję Zygmunta Zaremby, trafnie zauważającego, że wzniosłe idee adresowane do ogółu często 
Szczególnie trafne wydają się oceny Machajskiego dotyczące nieuchronnego powstawania mechanizmów zniewolenia i wyzysku po rewolucji socjalistycznej, czyli po likwidacji prywatnej własności środków produkcji. Przypominaja one wywody wielu myślicieli, przede wszystkim Đilasa piszącego o „nowej klasie"96. W ujęciu Machajskiego jest nią inteligencja; gdy tylko dostawała się „do władzy”, zawsze „okazywała się najdrapieżniejszym władcą niewolników, szatańsko mądrym i najsroższym pogromcą" ${ }^{\prime 2}$. W takim przekonaniu utrzymywały Machajskiego wydarzenia w Rosji w pierwszych latach po rewolucji lutowej i po przechwyceniu władzy przez bolszewików w październiku $1917 \mathrm{r}$. W połowie tego roku Machajski opuścił Paryż - tam wówczas przebywał - i na pokładzie rosyjskiego statku wypływającego z Hawru udał się do Petersburga. Miał wówczas stwierdzić, że „to nie moja jeszcze rewolucja, ale rewolucja”98. Pobyt w Rosji utwierdzał go w tej ambiwalencji. Miał nadzieję, że rosyjskiemu

ukrywaja dosyć trywialne, banalne interesy jednostek. Zaremba zapytuje, czy „krytyka Machajskiego pod adresem ruchów rewolucyjnych i wolnościowych XIX i początku XX wieku" nie „uderzała często bardzo celnie, wydobywając na jaw skryte tendencje, dalekie od głoszonych celów?” Przecież „duch ludzki wyćwiczył się w ukrywaniu przed świadomościa jednostek podskórnych pobudek egoizmu i wygodnictwa pod błyszczącym pokostem wielkich idei”. Zaremba trafnie sugeruje „rozszczepienie między ideologia a polityka”, dostrzega „perspektywy nowego oszustwa mas i nadużycia ruchów rewolucyjnych dla celów obcych proletariatowi”. Z. Zaremba, op. cit., s. 126-127. W tej właśnie perspektywie można by przytoczyć na przykład nie tyle socjalistyczne, narodowe czy patriotyczne, co osobiste i psychologiczne, $\mathrm{w}$ istocie egoistyczne motywy działania, ujawnione przez Piłsudskiego w liście do Feliksa Perla z września 1908 r.: „Walczę i umrę, jedynie dlatego, że w wychodku, jakim jest nasze życie, żyć nie mogę, to ubliża [...] mi, jako człowiekowi z godnością nie niewolnicza. Niech inni się bawią w hodowanie kwiatów, czy socjalizmu, czy polskości [podkreślenie - M.J.Z.], czy czego innego w wychodkowej (nawet nie klozetowej) atmosferze - ja nie mogę! To nie sentymentalizm, nie mazgajstwo, nie maszynka ewolucji społecznej, czy tam co, to zwyczajne człowieczeństwo. Chcę zwyciężyć, a bez walki [...] jestem nie zapaśnikiem nawet, ale wprost bydlęciem, okładanym kijem czy nahajką. J. Piłsudski, List do Feliksa Perla, w: idem, Wybór pism, Kraków 1999, s. 69-70. Na instrumentalne potraktowanie robotniczej bazy przez inteligencję po 1989 r. w Polsce zwraca zaś uwagę Walicki, pisząc o „przerzucaniu się” od „wulgarnego socjalizmu w wulgarny kapitalizm” i oceniając „że w wielu wypadkach mieliśmy do czynienia ze spełnieniem przewidywań Jana Wacława Machajskiego, że inteligencja, czyli "posiadacz kapitału umysłowego», wykorzysta ruch robotniczy instrumentalnie, jako narzędzie własnych interesów”. A. Walicki, W odpowiedzi na ankiete Stowarzyszenia Studiów i Inicjatyw Spotecznych, „Przegląd”, 6 XI 2003, s. 3; idem, Od projektu komunistycznego do neoliberalnej utopii, Kraków 2013, s. 280-282.

${ }^{96}$ Oprócz Đilasa mam tu na myśli przede wszystkim Michaiła Bakunina, Bertranda Russella, Nikołaja Bierdiajewa, Nikołaja Bucharina. Szczegóły zob. M.J. Zacharias, Intelligentsia and New Class..., s. 163-165; idem, Putevi i bespuća..., s. 354-356.

${ }^{97}$ J.W. Machajski, Religia socjalistyczna..., s. 264-265. Tu należałoby dodać, że w XIX w. i na przełomie XIX i XX stulecia krytyczną wizję znaczenia i pozycji polskiej inteligencji, w duchu Machajskiego, przedstawiali: Edward Dembowski, Stanisław Brzozowski i Edward Abramowski. Zob. A. Walicki, O inteligencji...,s. 64-66; L. Dubel, Zapomniany prorok rewolucji..., s. 119, 121-124.

${ }^{98}$ Z. Zaremba, op. cit., s. 95. 
proletariatowi uda się wywłaszczyć całe społeczeństwo burżuazyjne, a więc zlikwidować wszelkie formy własności. Niemniej w bieżących wydarzeniach dostrzegał przede wszystkim groźbę, że w dawnej monarchii Romanowów będzie rządziła bezwzględna „nowa burżuazja”, „ludowa burżuazja”, składająca się z ,inteligentów i półinteligentów” z szeregów robotniczych; niedawnych rewolucjonistów, którzy „po rewolucji październikowej” stawali się „państwowymi funkcjonariuszami”99. Tak zwaną dyktaturę proletariatu „traktowali [...] jako szczególna, odrębną władzę oświeconego społeczeństwa”, czyli inteligencji ${ }^{100}$. Można by dyskutować, czy lub w jakim stopniu była to władza „pracowników umysłowych”. Jednakże ocena, że nowa władza stanowiła kolejną formę wyzysku i zniewolenia, poraża swoją trafnością.

Machajski zmarł w osamotnieniu 19 II 1926 r. Pochowany został w Moskwie ${ }^{101}$. Poza wspomnianym Nachtem nie pozostawił innych, szerzej znanych uczniów i kontynuatorów. Głównie dlatego, że choć w dużej mierze trafne, jego poglądy były niezwykle skrajne. Bezwzględne i bezdyskusyjne

${ }_{99}$ M.S. Shatz, op. cit., s. 153.

${ }^{100}$ L. Dubel, Zapomniany prorok rewolucji..., s. 142-143. Jak pisze Dubel, „Machajski nie dostrzegał większej różnicy pomiędzy leninowską koncepcją dyktatury proletariatu a tym, co głosili zwolennicy drogi parlamentarnej”. Ibidem, s. 145, przypis 415; L. Dubel, Idea Zmowy Robotniczej w ujęciu J.W. Machajskiego, „Annales UMCS” 1988, sectio G, t. XXXV, nr 1, s. 227. Należałoby zauważyć, że tezy Machajskiego do pewnego stopnia były zgodne z wywodami Lenina. Twierdził on, że socjalizm wyrasta „z tych teorii filozoficznych, historycznych i ekonomicznych, które wypracowane zostały przez wykształconych przedstawicieli klas posiadających, przez inteligencję”; że „współczesna świadomość socjalistyczna może powstać tylko na podstawie głębokiej wiedzy naukowej”, a więc jest „czymś z zewnątrz wniesionym do walki klasowej proletariatu, a nie czymś powstałym z niej żywiołowo”. Zob. W.I. Lenin, Dzieła, t. V, Warszawa 1950, s. 441, 420; A. Walicki, Zarys myśli rosyjskiej. Od oświecenia do renesansu religijno-filozoficznego, Kraków 2005, s. 670. Niemniej przywódca bolszewików był zaniepokojony faktem, że rosyjski „ruch robotniczy dojrzewa niezależnie od socjaldemokratycznej inteligencji i trzyma się z dala od walki politycznej”. Ta rezerwa rosyjskiego proletariatu była zgodna z postulatami Machajskiego, zalecajacego przecież prymat walki ekonomicznej nad polityczna. Inna rzecz, że przerastającej w rewolucję, choć bez inteligencji i przeciw inteligencji, w oderwaniu od socjalizmu. Lenin zaś twierdził, że „oderwany od socjaldemokracji ruch robotniczy [...] nieuchronnie popada w burżuazyjność". Niekierowani przez partię socjalistyczną robotnicy niechybnie zdradzaja własne interesy klasowe, sprawę rewolucji i popadają w „ekonomizm” będący w istocie rosyjską odmianą rewizjonizmu Bernsteina. W rezultacie przywódca bolszewików głosił, „że proletariatem dla jego własnego dobra musi kierować elita wybrańców”, tj. zwarta, zdyscyplinowana i hierarchiczna organizacja partyjna. Zgodnie z zasada, że „tylko nierobotnicy - w domyśle: inteligencja-wiedza, jakie [...] są interesy” robotników. R. Pipes, Rewolucja rosyjska..., s. 283-285. Takie założenia były całkowicie sprzeczne z poglądami Machajskiego, szczególnie dostrzegalny w przytoczonych wywodach interes przywódcy rosyjskiej socjaldemokracji w wywołaniu rewolucji kierowanej przez inteligentów, zawodowych rewolucjonistów. Ponadto w odróżnieniu od Lenina Machajski był przekonany, że to nie oderwanie, a przeciwnie - współdziałanie z inteligenckimi partiami socjaldemokratycznymi sprzyja podporządkowaniu proletariatu celom i zamysłom burżuazji.

${ }^{101}$ D. Zych, op. cit., s. 180. 
potępienie każdej formy socjalizmu musiało doń zrażać socjalistów. A przecież jeżeli gdzieś miał szukać zwolenników, to właśnie jedynie w ich szeregach.

\section{Streszczenie}

W artykule zostały przedstawione poglądy Jana Wacława Machajskiego (1866-1926), dotyczące socjalizmu, rewolucji oraz politycznej roli i pozycji inteligencji, tj. tej warstwy społecznej, która na przełomie XIX i XX stulecia miała szczególne znaczenie, przede wszystkim w Europie Wschodniej i Środkowo-Wschodniej. Machajski, szkolny przyjaciel wybitnego pisarza Stefana Żeromskiego, był szczególnym, specyficznym myślicielem, analitykiem procesów społecznych i politycznych. Paradoksalnie bowiem mieścił się i wyłamywał z socjalistycznych schematów myślenia i preferowanych form działania. Z jednej strony głosił potrzebę przeprowadzenia - jak można by powiedzieć - „rewolucji proletariackiej”, z drugiej zaś zdecydowanie potępiał wszelkie formy i odmiany socjalizmu. W swojej twórczości wyraźnie ustawiał się w roli przeciwnika socjalistów, zarówno tych, którzy mówili o potrzebie własnej, jak uważał, socjalistycznej rewolucji, jak i tych, którzy wzorem Eduarda Bernsteina preferowali ewolucyjne dążenia - rewizjonistyczne i reformistyczne. Taka postawa wynikała z przekonania, że wszelkie koncepcje, teorie, ideologie i działania socjalistyczne, z marksizmem na czele, sa jedynie metodą zabezpieczenia interesów inteligentów, „pracowników umysłowych”; interesów całkowicie sprzecznych z interesami i potrzebami proletariatu. Wynika to z faktu - pisze Machajski - że wspólnie z burżuazja, a więc właścicielami kapitału i środków produkcji, inteligencja uczestniczy w wyzysku, tj. w przywłaszczaniu tzw. wartości dodatkowej i podobnie jak ona, jest częścią społeczeństwa burżuazyjnego. Zdaniem Machajskiego to nie tyle burżuazja, jak głosił Marks i jego zwolennicy, co „stale rosnące społeczeństwo burżuazyjne”, a więc także inteligencja to śmiertelny wróg proletariatu. W ujęciu polskiego myśliciela inteligencja jest grupa interesu wybitnie egoistyczna, pozbawioną jakiegokolwiek etosu czy altruizmu, poczucia odpowiedzialności i służebności wobec słabszych grup społecznych. Warstwą aspirujacca do wysokiego statusu materialnego oraz władzy, manipulujacca teoria i praktyką socjalizmu. W rezultacie przyszła rewolucja musi być przeprowadzona bez udziału inteligencji i przeciw inteligencji, istotnej części społeczeństwa burżuazyjnego. W koncepcji Machajskiego odrzucenie każdej formy socjalizmu jest koniecznym, niezbędnym warunkiem powodzenia przyszłej, robotniczej rewolucji. Ostatecznie bezwzględne i bezdyskusyjne potępienie socjalizmu musiało doń zrażać socjalistów. A przecież jeżeli gdzieś miał szukać zwolenników, to właśnie tylko w ich szeregach.

\section{Intelligentsia, Socialism, and Revolution in Political Thought of Jan Wacław Machajski (1866-1926)}

The article presents the views of Jan Wacław Machajski (1866-1926) on socialism, revolution, and the political role and position of the intelligentsia, that is the social strata which at the turn of the twentieth century was of particular importance, especially in Eastern and Central Eastern Europe. Machajski, a school friend of outstanding writer Stefan Żeromski, was a special, specific thinker, an analyst of social and political processes. Paradoxically, he both fitted in and broke away from socialist thinking schemes and preferred forms of action. On the one hand, he preached the need for - as one might say - a "proletarian revolution," while on the other, he strongly condemned all forms and varieties of socialism. In his work, he clearly positioned himself as the opponent of the socialists, both those who spoke about the need of their own, as he felt, socialist revolution, and those who, like Eduard Bernstein, 
preferred evolutionary aspirations: revisionist and reformist. Such an attitude resulted from the conviction that all concepts, theories, ideologies and socialist actions, with Marxism at the forefront, were only a method of safeguarding the interests of intellectuals, "white-collar workers"; interests completely contrary to the interests and needs of the proletariat. This was due to the fact - Machajski wrote - that together with the bourgeoisie, and thus the owners of capital and means of production, the intellectuals participated in exploitation, i.e. in the appropriation of the so-called surplus value and, like them, were part of bourgeois society. According to Machajski, it was not so much the bourgeoisie as Marx and his followers proclaimed, but "an ever-growing bourgeois society," and therefore the intelligentsia was the deadly enemy of the proletariat. According to the Polish thinker, the intelligentsia was a very selfish interest group, devoid of any ethos or altruism, a sense of responsibility and servitude towards weaker social groups. A strata aspiring to high material status and power, manipulating the theory and practice of socialism. As a result, the future revolution had to be carried out without the participation of intelligentsia and against intelligentsia, a significant part of bourgeois society. In Machajski's concept, the rejection of any form of socialism was a necessary and indispensable condition for the success of the future workers revolution. Ultimately, the ruthless and firm condemnation of socialism must have had alienated socialists. And if he was to look for supporters somewhere, it was only within their ranks.

\section{Bibliografia}

Aron R., L'opium des intellectuels, Paris 1955.

Bell D., The End of Ideology. On the Exhaustion of Political Ideas in the Fifties, Glencoe 1960. Agostino A. d', Intelligentsia Socialism and the „Worker's Revolution”. The Views of J.W. Machajski, „International Review of Social History” 1969, nr 4.

Djilas M., The Unperfect Society. Beyond the New Class, New York 1973.

Dubel L., Idea Zmowy Robotniczej w ujęciu Jana Wacława Machajskiego, „Annales UMCS” 1988, sectio G, t. XXXV, nr 1.

Dubel L., Totalna negacja inteligencji. Idee Jana Wacława Machajskiego i Michała Bakunina, „Studia nad Autorytaryzmem i Totalitaryzmem” 2016, t. XXXVIII, nr 4.

Dubel L., Zapomniany prorok rewolucji. Szkic o Janie Wactawie Machajskim, Lublin 2009.

Dubel L., Życiowe przypadki i wybory Jana Wactawa Machajskiego, w: J.W. Machajski, Robotnik umystowy 1911, oprac. L. Dubel, Zamość 2012.

Fourastié J., Les trente glorieuses: ou la révolution invisible de 1946 à 1975, Paris 1975.

Gawor L., Filozofia społeczna Jana Wactawa Machajskiego, „Archiwum Historii Filozofii i Myśli Społecznej” 2009, t. LIV.

Gawor L., Machajskiego teoria socjalistycznej rewolucji, „Wschodni Rocznik Humanistyczny” 2007, t. IV.

Hobsbawm E., Wiek skrajności. Spojrzenie na Krótkie Dwudzieste Stulecie, tłum. M. Król, J. Kalinowska-Król, Warszawa 1999.

Janowski M., Inteligencja jako kategoria społeczna - fenomen środkowoeuropejski?, w: Cywilizacja europejska, t. III: Różnorodność i podziaty, red. M. Koźmiński, Kraków 2014, s. $227-250$.

Judt T., Powojnie. Historia Europy od roku 1945, tłum. R. Bartołd, Poznań 2008.

Kamiński A.A., Socjalizm jako wymyst inteligencji. O życiu i pogladach Jana Wactawa Machajskiego, „Prace Naukowe Akademii Ekonomicznej we Wrocławiu. Nauki Humanistyczne" 2003, t. VIII, s. 48-72.

Keynes J.M., The General Theory of Employment, Interest and Money, New York 1935 (wyd. pol.: Ogólna teoria zatrudnienia, procentu i pieniadza, tłum. M. Kalecki, S. Raczkowski, Warszawa 1956). 
Kołakowski L., Główne nurty marksizmu, t. I, Warszawa 2009.

Król M., Koniec wieku ideologii, www.newsweek.pl/europa/koniec-wieku-ideologii,44602,1,1,. html (dostęp: 18 XI 2016).

Laskowski P., Jan Wacław Machajski: jasnowidz i prorok, w: J.W.Machajski, Pracownik umystowy $i$ inne pisma, wprowadzenie, red. nauk. P. Laskowski, tłum. S. Kowalski, Warszawa 2016, s. 7-88.

Machajska W., Życie i poglady Wactawa Machajskiego, „Wiadomości” (Londyn), 4 III 1962, nr 9 (831).

Nomad M., Dreamers, Dynamiters and Demagogues, New York 1964.

Nomad M., The Saga of Jan Waclaw Machajski, w: Aspects of Revolt, New York 1959.

Pipes R., Piotr Struwe. Liberat na lewicy 1870-1905, tłum. S. Szymański, Warszawa 2016.

Pipes R., Rewolucja rosyjska, tłum. T. Szafar, Warszawa 1994.

Piskała K., Socjalizm jako spisek, http://numery.praktykateoretyczna.pl/PT_nr6_2012_Roza_ Luksemburg/21.Piskala.pdf (dostęp: 22 II 2016).

Shatz M.S., Jan Wactaw Machajski. A Radical Critic of the Russian Intelligentsia and Socialism, Pittsburgh (Pa.) 1989.

Walicki A., O inteligencji, liberalizmach i o Rosji, Kraków 2007.

Walicki A., Od projektu komunistycznego do neoliberalnej utopii, Kraków 2013.

Walicki A., W odpowiedzi na ankiete Stowarzyszenia Studiów i Inicjatyw Spotecznych, „Przegląd”, 6 XI 2003, s. 3.

Walicki A., Zarys myśli rosyjskiej. Od oświecenia do renesansu religijno-filozoficznego, Kraków 2005.

Wilson E., Max Nomad and Waclaw Machajski, https://edmund-wilson-max-nomad-andwaclaw-machajski (dostęp: $23 \mathrm{~V} 2019$ ).

Zacharias M.J., Idee, utopie, rzeczywistość. Myśl polityczna Milovana Dilasa (1911-1995), Bydgoszcz 2015.

Zacharias M.J., Intelligentsia and a New Class. Political elites according to Jan Wactaw Machajski and Milovan Djilas, „Studia z Dziejów Rosji i Europy Środkowo-Wschodniej” 2017, t. LII, Special Issue, z. 3.

Zacharias M.J., Putevi i bespuća revolucionarne misli. Slučaj Jana Vaclava Mahajskog i Milovana Đilasa, w: Jugoslavija i Poljska u XX veku. Međunarodni tematyki zbornik radova sa konferencije Jugoslovensko-poljski odnosi u XX veku, red. M. Pavlović, A. Zaćmiński, P. Wawryszuk, Beograd 2017, s. 349-374.

Zaremba Z., Stowo o Wactawie Machajskim, Paryż 1967.

Zych D., Jan Wactaw Machajski (Zagadnienia biografii), w: Historia i kultura. Studia $z$ dziejów polskiej myśli kulturalnej, t. II, red. A. Mencwel, Warszawa 1991, s. 159-186.

Żywczyński M., Historia powszechna 1789-1870, Warszawa 1967.

Biog r a m: Michał J. Zacharias - prof. dr hab.; w latach 1990-2007 pracował w Instytucie Historii PAN. Od 1999 r. związany z Wyższą Szkołą Pedagogiczną w Bydgoszczy (obecnie Uniwersytet Kazimierza Wielkiego), emerytowany pracownik Wydziału Nauk o Polityce i Administracji UKW. Obszar zainteresowań: historia powszechna i Polski XX w., szczególnie polityka międzynarodowa, polska polityka zagraniczna, Jugosławia, elity, ustroje i myśl polityczna tego stulecia. E-mail: michal.j.zacharias@gmail.com. 